\title{
BIOFUEL CELLS AS A POSSIBLE POWER SOURCE FOR IMPLANTABLE ELECTRONIC DEVICES
}

\author{
by \\ Gusphyl A. Justin \\ BS, BA, University of Pittsburgh, 2001
}

\author{
Submitted to the Graduate Faculty of \\ the School of Engineering in partial fulfillment \\ of the requirements for the degree of \\ Master of Science
}

University of Pittsburgh

2004 


\section{UNIVERSITY OF PITTSBURGH \\ SCHOOL OF ENGINEERING}

This thesis was presented

by

Gusphyl A. Justin

It was defended on

April 2, 2004

and approved by

Mingui Sun, Associate Professor, Department of Neurological Surgery

Robert Sclabassi, Professor, Department of Neurological Surgery

Harvey Borovetz, Professor, Department of Bioengineering

Thesis Advisor: Mingui Sun, Associate Professor, Department of Neurological Surgery 


\title{
BIOFUEL CELLS AS A POSSIBLE POWER SOURCE FOR IMPLANTABLE ELECTRONIC DEVICES
}

\author{
Gusphyl A. Justin, M.S. \\ University of Pittsburgh, 2004
}

A major challenge facing the development of implantable devices for clinical use is in finding a suitable power source for such devices. The power source should be able to generate an electric current for extended periods of time. Biofuel cells (BFC) provide some promise in this respect, as their function is primarily based on coupling the oxidation of glucose to the reduction of molecular oxygen to water. Under ideal conditions, the only byproducts of the BFC would simply be carbon dioxide and water.

Both glucose and oxygen are present in the cells and tissues of all eukaryotic organisms, including human beings. It might, therefore, be possible to tap into the body's own resources, including the metabolic properties of our cells, to generate enough energy to power an array of clinical devices - including drug delivery systems, diagnostic tools, and human augmentation devices.

The experiments described in this paper serve as a first step toward the goal of designing and developing a $\mathrm{BFC}$ that would be based on transducing the power of oxidative metabolism within our own cells into an electrical current.

In the first phase of our experiments, the function and current output of a specific type of $\mathrm{BFC}$, called a microbial fuel cell (MFC) is investigated. The behavior and characteristics of such biofuel cells have been well documented in the scientific literature. MFCs essentially convert the biochemical energy of bacteria into electrical energy. A strain of Escherichia Coli is used in our study. In the second phase of our experiments, an attempt is made to derive electrical currents from BFCs employing human white blood cells. 


\section{TABLE OF CONTENTS}

1.0 BACKGROUND . . . . . . . . . . . . . . . . . . . . . . 1

1.1 Fuel Cells . . . . . . . . . . . . . . . . . . . . 1

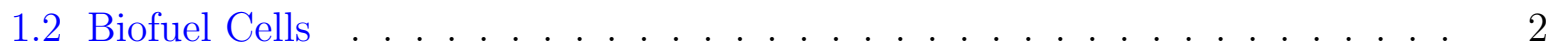

1.3 Glucose Metabolism and the Electron Transport Chain . . . . . . . . . . . . 4

1.4 Electron transport in white blood cells . . . . . . . . . . . . . . 5

2.0 MICROBIAL FUEL CELLS . . . . . . . . . . . . . . . . . 7

2.1 Introduction ........................... 7

2.2 Anode Compartment . . . . . . . . . . . . . . . . . 8

2.3 Cathode Compartment . . . . . . . . . . . . . . . . 9

2.4 Anode and Cathode Reactions . . . . . . . . . . . . . . . . . . . . 10

2.5 Proton Exchange Membrane . . . . . . . . . . . . . . . . . . . 10

2.6 Electron Mediators . . . . . . . . . . . . . . . . . . . 12

3.0 MICROBIAL FUEL CELL EXPERIMENT I . . . . . . . . . . . . . . 14

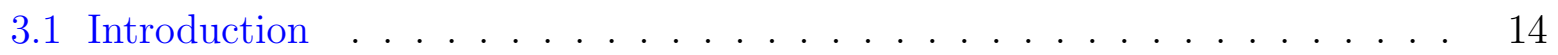

3.2 Apparatus/Materials . . . . . . . . . . . . . . . . . . 14

3.3 Methods................................ 15

3.3 .1 Stock Solutions . . . . . . . . . . . . . . . 15

3.3 .2 Bacterial culture . . . . . . . . . . . . . . 15

3.3.3 Biofuel Cell Design and Preparation . . . . . . . . . . . . . 16

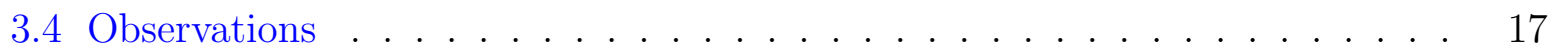

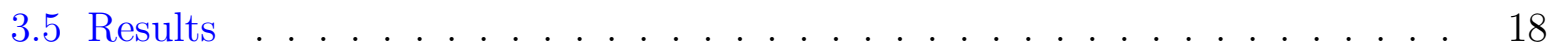

3.6 Determining the maximum possible power output . . . . . . . . . . . . 20 
3.7 Calculation of current output under optimal conditions . . . . . . . . . . 20

3.8 Conclusions . . . . . . . . . . . . . . . . . . . . . . . 21

4.0 MICROBIAL FUEL CELL EXPERIMENT II . . . . . . . . . . . . . . 22

4.1 Introduction . . . . . . . . . . . . . . . . . . . 22

4.2 Apparatus/Materials . . . . . . . . . . . . . . . . . 22

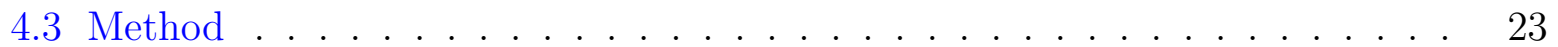

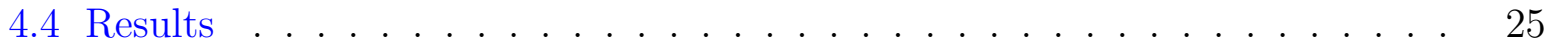

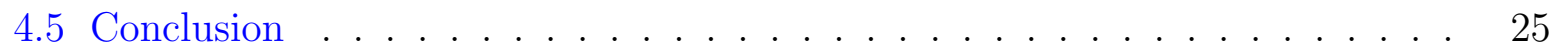

5.0 DISCUSSION OF MFC EXPERIMENTS . . . . . . . . . . . . . . 28

6.0 LEUKOCYTE BIOFUEL CELL . . . . . . . . . . . . . . . . . . 30

6.1 Introduction . . . . . . . . . . . . . . . . . . 30

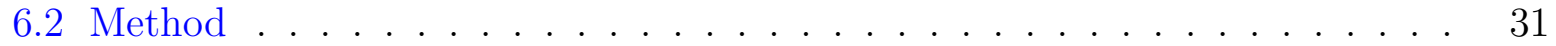

6.2.1 Biofuel cell . . . . . . . . . . . . . . . . . . . . . . . . . 31

6.2.2 Acquisition of neutrophils and B and T lymphocytes . . . . . . . . . . 31

6.2.3 Preparation of Biofuel Cell . . . . . . . . . . . . . . . . . . 31

6.3 Observations . . . . . . . . . . . . . . . . . . . . 32

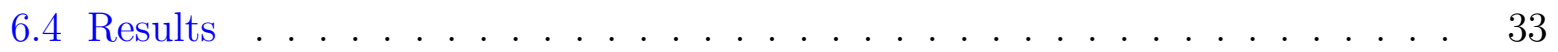

6.5 Conclusion . . . . . . . . . . . . . . . . . . . . . 33

7.0 DISCUSSION OF LEUKOCYTE BFC EXPERIMENTS . . . . . . . . . 41

BIBLIOGRAPHY . . . . . . . . . . . . . . . . . . . . 43 


\section{LIST OF TABLES}

1 Maximum and minimum current densities $\left(\mu \mathrm{A} / \mathrm{cm}^{2}\right)$ for the $50 \Omega, 100 \Omega$, and $500 \Omega$ resistors. . . . . . . . . . . . . . . . . . . . .

2 Maximum and minimum neutrophil current densities $\left(\mu \mathrm{A} / \mathrm{cm}^{2}\right)$ for the $50 \Omega$, $100 \Omega$, and $500 \Omega$ resistors (Experiment 3) . . . . . . . . . . .

3 Maximum and minimum neutrophil current densities $\left(\mu \mathrm{A} / \mathrm{cm}^{2}\right)$ for the $100 \Omega$ resistor $($ Experiment 4$) \ldots \ldots \ldots \ldots \ldots \ldots$ 


\section{LIST OF FIGURES}

1 Illustration of a Microbial Fuel Cell with Methylene blue (MB) as the electron

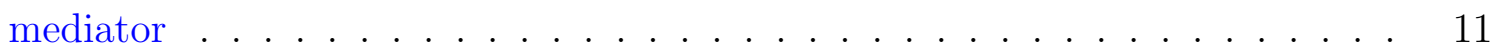

2 Methylene blue . . . . . . . . . . . . . . . . . . . 12

3 Biofuel Cell Setup (Front View) . . . . . . . . . . . . . . . 17

4 Measurements of current, current density and electromotive force acquired from the microbial fuel cell . . . . . . . . . . . . . . . . . . . . 19

5 Microbial fuel cell experimental setup to test whether E. Coli is able to generate an electrical current. The apparatus was assembled from parts acquired in a toolkit from the National Center of Biotechnology Education (NCBE). . . . .

6 Current densities from microbial fuel cell experiment 2. Current density decreased rapidly over the first hour of measurement after which a gradual levelling off could be observed. Effects of polarization, increased electron transfer to molecular oxygen and cell death could be attributed to these observations.

7 Current densities from Microbial Fuel Cell (MFC) Experiments 1 and 2. Experiment 1 lacked a load. In Experiment 2, however, a $500 \Omega$ load was used. The results from Expt. 2 seem to suggest that the effects of polarization are reduced when the MFC is placed in series with a sufficiently large resistance.

8 Comparison of current densities from Experiment 2 (MFC Experiment II) and Experiment 3 (first leukocyte biofuel cell experiment). $50 \Omega$ resistor (Top); $100 \Omega$ resistor (Middle); $500 \Omega$ resistor $($ Bottom) . . . . . . . . . . . . 
9 Current densities acquired from biofuel cell. Current densities were acquired using a circuit with a $100 \Omega$ resistor. Differences can be seen in the current generated between the first and second leukocyte biofuel cell trials (Expt 3 and Expt 4 respectively). . . . . . . . . . . . . . . .

10 Current densities acquired from biofuel cell (Experiment 5). Current densities were acquired using a circuit with a $100 \Omega$ resistor. The antioxidant, NAC, increased the current slightly, however, a drop occurs upon addition of the nonionic detergent, Igepal. In the instance of the control (no cells), an increase in the current density was observed on addition of PMA/ionomycin. This might be due to some cells remaining even after the biofuel cell container was washed

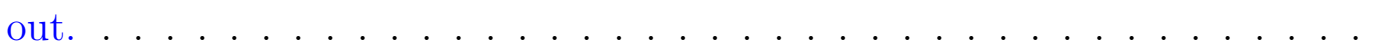

11 Comparison of the current densities acquired from the leukocyte biofuel cell in three different trials (Experiments 3,4 and 5). These were in turn compared to an additional experimental trial without cells included in the preparation. . 38

12 Current densities acquired from the leukocyte biofuel. . . . . . . . . . . . 


\subsection{BACKGROUND}

\subsection{FUEL CELLS}

Fuel cells are devices that convert the chemical energy of a fuel into electricity by electrochemical reactions [4]. They differ from storage cells in that an electrical power output can be sustained almost indefinitely, as long as a fuel can be continuously supplied [5]. The term fuel cell is often specifically applied to hydrogen-oxygen fuel cells. In order to generate electricity, electrons are stripped from hydrogen gas $\left(H_{2}\right)$ molecules to form protons $\left(H^{+}\right)$. The protons then traverse a proton exchange membrane (PEM), combining with oxygen $\left(O_{2}\right)$ to form water. Fuel cells are usually much more efficient than other types of energy converters. Energy conversion efficiencies as high as 60-80\% have been achieved [4]. A higher efficiency would mean that a smaller storage container, as well as less fuel would be needed for a specific energy requirement. In addition to the high levels of efficiency attainable, another advantage of fuel cells is the fact that they are capable of supplying electrical energy over a much longer period of time. Unlike a battery, which contains only a limited amount of fuel material and oxidant, fuel cells are continuously supplied with fuel and air (or $O_{2}$ ) from an external source. They also differ from internal-combustion devices, where a fuel is burned and gas is expanded to do work, in that they convert chemical energy directly into electrical energy. The development of fuel cells offer many advantages over other types of power sources in that they demonstrate a high efficiency, do not emit pollutants and provide a truly sustainable power output if hydrogen is produced from a renewable energy source [5]. 


\subsection{BIOFUEL CELLS}

Recently, a number of papers have been published describing experiments to investigate current and power output from a specific type of biofuel cell called a microbial fuel cell (MFC). MFCs are based on the coupling of glucose oxidation to the reduction of molecular oxygen to water. Electrons are "hijacked" from the electron transport chain, which occurs in the bacterial plasma membrane, and shuttled to electrodes where they begin their journey through an electric circuit. To increase the efficiency of electron transfer from the plasma membrane to the electrodes, electron mediators (electronophores) have been employed. These molecules have special properties, which permit their insertion across the plamsa membrane of microbes. They tap into the electron transport chain, becoming reduced in the process, after which they become reoxidized by transferring electrons to the fuel cell's anode. Common electronophores include neutral red, methylene blue and thionin.

Complete oxidation of one mole of glucose to carbon dioxide would liberate 24 moles of electrons.

$$
\mathrm{C}_{6} \mathrm{H}_{12} \mathrm{O}_{6}+6 \mathrm{H}_{2} \mathrm{O} \rightarrow 6 \mathrm{CO}_{2}+24 e^{-}+24 \mathrm{H}^{+}
$$

Therefore, a total of $2.32 \times 10^{6} \mathrm{C}$ of charge per mole of glucose is potentially available to be channeled through an electrical circuit. The magnitude of the current generated from this oxidative process would depend largely on:

- the rate of metabolism and

- the efficiency of electron transfer to the electrode.

A number of other factors are involved in the size of the generated currents, which will be discussed later. Some success has been achieved in the conversion of the biochemical energy involved in glucose metabolism into electrical energy.

Microbial fuel cells consist of two compartments separated by a proton exchange membrane (PEM). One compartment houses the anode, while the other houses the cathode. The principle of function of such biofuel cells is strongly related to biochemical processes that occur within microbial organisms, namely glycolysis, the citric acid cycle and the electron transport chain. Electronophores intervene during the electron transport process, carrying electrons from the bacterial plasma membrane to the anode (negative electrode). These elec- 
trons travel through an electric circuit and subsequently reduce ferricyanide to ferrocyanide at the cathode (positive electrode). Protons pumped from the bacteria into the anode environment traverse the PEM into the cathode compartment. Ferrocyanide is reoxidized to ferricyanide, while the hydrogen ions combine with oxygen to form water.

$$
\begin{aligned}
& 4 \mathrm{Fe}(\mathrm{CN})_{6}^{3^{-}}+4 e^{-} \rightarrow 4 \mathrm{Fe}(\mathrm{CN})_{6}^{4^{-}} \\
& 4 \mathrm{Fe}(\mathrm{CN})_{6}^{4^{-}}+4 \mathrm{H}^{+}+\mathrm{O}_{2} \rightarrow 4 \mathrm{Fe}(\mathrm{CN})_{6}^{3^{-}}+2 \mathrm{H}_{2} \mathrm{O}
\end{aligned}
$$

Based on the present knowledge of biofuel cells' function, efforts have been made to maximize current and power outputs in MFCs by:

- comparing and employing different combinations of bacteria and electronophores [2],[12],[14]

- the use of mixed bacteria cultures [3],[11],[13]

- the use of an anaerobic (non-oxygenated) atmosphere at the anode [2],[6],[7],[10],[11],[12],,[13]

- increasing feeding rates of fuel (sugars) [13]

- modification of electrodes such as immobilization of electronophores [2],[10],[11],[12], and use of conductive polymers [15]

- bubbling oxygen through the cathode compartment [2],[10].

Current densities as high as $1.5 \mathrm{mAcm}^{-2}$ have been reported from microbial fuel cells [13],[15] and power outputs of up to $3.6 \mathrm{Wm}^{-2}$ [13]. Rabaey et al [13] used a mixed bacterial culture in their experiments and investigated the effect of differential glucose feeding rates on the power output. Plain graphite electrodes were used. Electron recovery of up to $89 \%$ was observed in terms of electricity for glucose feeding rates in the range of $0.5 \mathrm{~g} \mathrm{~L}^{-1}$ per day. The power output achieved in this study was 5 fold higher than that reported previously.

In the study by Schroeder et al [15], a novel polymer-modified catalytically active anode was constructed and employed. The anode used was a polyaniline modified platinum electrode. A Escherichia Coli K12 bacterial culture was used in the study. The most evident disadvantage of the entire process was the cost of producing the electrodes. Current densities comparable to those of Rabaey et al [13] were achieved. Previous literature values for the MFC currents normally ranged between $1 \mu \mathrm{Acm}^{-2}$ and $30 \mu \mathrm{Acm}^{-2}$.

Several papers ensured an anaerobic atmosphere at the anode [2],[6],[7],[10],[11],[12] and bubbled oxygen through the cathode compartment [2],[10]. These factors both contribute to 
higher current outputs. An anaerobic atmosphere was usually provided by passing nitrogen and carbon dioxide gas through the anode compartment. Eliminating the presence of oxygen would lead to increased transfer of electrons from the bacteria to the electrode, rather than to oxygen. Bubbling breathing air through the cathode compartment promotes the reduction reaction of oxygen to water. As a result, the rate of oxygenation of the cathode has been shown to be a parameter that could be manipulated for optimization of the current generating system.

\subsection{GLUCOSE METABOLISM AND THE ELECTRON TRANSPORT CHAIN}

Metabolism refers to the entire network of chemical reactions performed by living cells [8]. All living organisms need energy. This energy requirement occurs at the cellular level and is essential for the numerous physiological processes that occur within higher, more complex species, as well as for the most basic functional activities of unicellular organisms, including prokaryotic cells. The "fuel" for providing this energy is usually in the form of glucose, which when oxidized to carbon dioxide $\left(\mathrm{CO}_{2}\right)$ and water $\left(\mathrm{H}_{2} \mathrm{O}\right)$ can release about $2800 \mathrm{~kJ} / \mathrm{mol}$ of energy. Much of this energy is transferred to individual acceptor molecules in a series of steps, rather than all at once, and is naturally more efficient than the latter, in terms of limiting energy loss. The energy released during catabolic reactions are conserved in the form of:

- nucleoside triphosphates, e.g. ATP and GTP

- reduced coenzymes, e.g. NADH and QH2

- ion concentration gradients

In the first stage of metabolism, glucose is converted by glycolysis to two molecules of pyruvate, during which ATP and NADH are produced. This occurs in the cytosol of the cell. In animal cells, the pyruvate is subsequently transported into the mitochondria where it is converted to $\mathrm{CO}_{2}$ and acetyl-CoA. The acetyl group is transferred to oxaloacetate, after which it participates in the citric acid cycle, also known as the tricarboxylic acid cycle or 
the Krebs cycle. This is the second phase in glucose metabolism.

The major end products are carbon dioxide and high energy electrons stored as NADH. Molecular oxygen itself does not participate in the citric acid cycle. However, $\mathrm{O}_{2}$ is essential to the process as it serves as the most efficient means for NADH to get rid of its electrons, regenerating $\mathrm{NAD}+$ and allowing the cycle to keep going. In the membrane-bound electron transport chain, NADH passes its high energy electrons to $\mathrm{O}_{2}$, which would later produce water, $\mathrm{H}_{2} \mathrm{O}$.

Oxidative phosphorylation is the third phase involved in the catabolism of glucose to produce energy and is a membrane-bound process. In eukaryotic cells, the process occurs within the mitochondrial membrane, while in prokaryotes, it occurs in the cellular membrane. It is also referred to as the electron transport chain. The process involves the transfer of electrons between electron carriers in order of reduction potential. As the electrons are passed down, toward the terminal oxidizing agent, usually molecular oxygen, protons are pumped across the membrane (from inside to outside) creating a transmembrane proton concentration gradient. As protons move back across the membrane, ADP is phosphorylated to form ATP. Electron carriers include NADH, $\mathrm{FADH}_{2}$ and $\mathrm{QH}_{2}$, which are coenzymes that reduce $\mathrm{O}_{2}$.

\subsection{ELECTRON TRANSPORT IN WHITE BLOOD CELLS}

Electron transport is generally not observed across the plasma membrane of eukaryotic cells (animal cells). However, recently a number of research articles have been published demonstrating that such electron currents do in fact exist in white blood cells. [17],[18],[19],[20].

A fascinating study, published in the journal Nature by a Swiss medical team, demonstrated that small currents can be measured across the plasma membrane of human eosinophil granulocytes [20]. The experiments were performed based on the hypothesis that the membrane associated enzyme NADPH oxidase, found in blood phagocytes, generates superoxide $\left(\mathrm{O}_{2}^{-}\right)$through electron transfer from NADPH to extracellular oxygen. In their investigation, the authors performed whole-cell recordings of the white blood cells in the presence of nitroblue tetrazolium (NBT). NBT turns dark blue in the presence of superoxide and was, therefore, used as a means of detecting activation of NADPH oxidase. The magnitudes of 
the currents recorded across the cellular membranes were on the order of 10 to $20 \mathrm{pA}$ per cell.

NADPH oxidase is in fact a complex of several proteins that associate with each other when activated [16],[18]. Activation in vitro was achieved by application of a phorbol ester, phorbol-12-myristate-13-acetate (PMA) [17],[19],[20].

In order to validate that the observed currents were in fact due to the presence of activated NADPH oxidase, Schrenzel et al [20] studied the effect of diphenylene iodinium (DPI), which blocked currents produced subsequent to agonist (PMA) stimulation. Eosinophils from patients with chronic granulomatous disease (CGD), a genetic defect, demonstrated only very small currents or no currents at all in this study. The presence or absence of NADPH did not significantly affect the observed currents in this case. CGD is associated with a dysfunctional NADPH oxidase complex. From these results, the authors were, therefore, able to confirm the importance of the NADPH oxidase complex in the generation of superoxide.

The Swiss medical team was also able to show the necessity of NADPH as an electron donor. This was done by investigating patients with a genetic defect called glucose-6phosphate-dehydrogenase deficiency (G6PD). The eosinophils of such patients have depleted stores of NADPH. Without NADPH, the eosinophils from G6PD patients demonstrated only very small currents. On addition of NADPH in vitro, currents were completely restored. 


\subsection{MICROBIAL FUEL CELLS}

\subsection{INTRODUCTION}

Two simple experiments were performed to explore current production in a specific type of BFC called a microbial fuel cell (MFC). Escherichia Coli (E. Coli) was used in these experiments, a microorganism often found in the human gut. Bacteriae such as E. Coli break down glucose in order to generate adenosine triphosphate (ATP), which is utilized by cells for energy storage. Methylene blue (MB) was used as an electron mediator, or electronophore, to efficiently facilitate the transfer of electrons from the microorganism to the electrode. Electron mediators tap into the electron transport chain, chemically reducing nicotinamide adenine dinucleotide $\left(\mathrm{NAD}^{+}\right)$to its protonated form NADH. The exact mechanism by which the transfer of electrons takes place through these electron mediators is not clear. However, it is known that they insert themselves into the bacterial membrane and essentially "hijack" the electron transport process of glucose metabolism.

Microbial fuel cells have been reported to generate current densities of up to $1.5 \mathrm{mAcm}^{-2}$ $[13],[15]$ and a power output of as much as $3.6 \mathrm{Wm}^{-2}$ [13]. Greater efficiency in electron transfer and thus an increase in current generation and power output have been attained by modifying graphite electrodes [11], using alternative electrodes [15], by employing a mixed bacterial culture [3],[11],[13], and using bacteria with higher metabolic rates. Different electron mediators have also been used to this end [14]. Park et al. [12] reported that a ten

fold more current was produced in their microbial fuel cell when neutral red (NR) was the electron mediator than when thionin was the electron mediator.

The biofuel cells used in this experiment consisted of two compartments, an anode compartment and a cathode compartment, separated by a proton exchange membrane (PEM). 
A number of papers mention the use of a Nafion film as the PEM, which allows hydrogen ions generated in the anode compartment to be transfered across the membrane into the cathode compartment [7],[6],[15],[12]. A disadvantage of the Nafion-117 film is the rather high cost of production.

Graphite electrodes were also used as the anode and cathode. Woven graphite felt might prove advantageous in that they provide a larger surface area, than a regular graphite electrode of similar dimensions, facilitating increased electron transfer from the microorganisms.

\subsection{ANODE COMPARTMENT}

The anode compartment would consist of the following:

- Bacteria (E.Coli)

- Glucose

- Electron mediator (methylene blue)

- Potassium Phophate buffer (pH 7.0)

- Graphite or Woven graphite felt electrode

The presence of electron mediators such as methylene blue and neutral red increase the efficiency of electron transfer. One paper reported that no current was observed in the absence of electron mediators [13].

As mentioned previously, these dyes insert themselves across the bacterial cellular membrane, and essentially hijack the electron transport chain. Noteworthy is the fact that the electron transport chain occurs in the cell membrane of prokaryotes, while the process occurs in the mitochondrial membrane of eukaryotes (animal cells). Attempts to substitute eukaryotic cells for bacterial cells in the design of a biofuel cell might, therefore, present a significant challenge.

Woven graphite felt would be ideally used for the electrodes, due to the large available surface area. Allen et al. [2] stated that graphite felt was chosen as the material for their electrodes because of its low resistance and its physical structure, which consists of an open 
network of interwoven fibers, providing easy access of the microbial organisms and mediator to the electrode surface.

For longterm experiments, glucose would need to be pumped into the anode compartment as a constant source of fuel for bacterial metabolism. Over time, oxidative metabolism would gradually decrease if there is a limited availability of glucose, which would be reflected in a decreasing current output. It would also be important to ensure that an anaerobic environment exists at the anode. In order to ensure anaerobic conditions, nitrogen gas should be passed through the compartment. The presence of oxygen at the anode would mean that the graphite electrodes would have to compete with molecular oxygen for electrons available through the electron transport chain. For a greater efficiency in electron transfer to the anode, it would be necessary to greatly reduce the concentration of dissolved oxygen.

Regulation of $\mathrm{pH}$ at the anode is important to consider. Increased acidity of the compartment could prove detrimental to the bacterial cells. Therefore, a phosphate buffer is used, which resists changes in $\mathrm{pH}$.

\subsection{CATHODE COMPARTMENT}

The cathode compartment of the microbial fuel cell would comprise of the following:

- Potassium ferricyanide

- Potassium Phosphate buffer (pH 7.0)

- Graphite or Woven graphite felt electrode

Potassium ferricyanide is an important component of the cathode compartment. The ferricyanide reaction is attractive for use at the cathode since it has a rapid electron uptake. Hydrogen ions $\left(\mathrm{H}^{+}\right)$migrate across the proton exchange membrane (PEM). The end product

at the cathode is water. The reactions observed at each of the electrodes are provided in the following section. The cathode compartment should be oxygenated by constant bubbling with air. This would promote the cathode reactions, where oxygen is reduced to water. 


\subsection{ANODE AND CATHODE REACTIONS}

In a microbial fuel cell, two redox couples are required in order to generate a current [12]:

- Coupling of the reduction of an electron mediator to bacterial oxidative metaboism.

- Coupling of the oxidation of the electron mediator to the reduction of the electron acceptor on the cathode surface. The electron acceptor is subsequently regenerated by the presence of $\mathrm{O}_{2}$ at the cathode surface. Refer to Figure 1.

At the anode:

$$
\mathrm{C}_{6} \mathrm{H}_{12} \mathrm{O}_{6}+6 \mathrm{H}_{2} \mathrm{O} \rightarrow 6 \mathrm{CO}_{2}+24 e^{-}+24 \mathrm{H}^{+}
$$

At the cathode:

$$
\begin{gathered}
4 \mathrm{Fe}(\mathrm{CN})_{6}^{3^{-}}+4 e^{-} \rightarrow 4 \mathrm{Fe}(\mathrm{CN})_{6}^{4^{-}} \\
4 \mathrm{Fe}(\mathrm{CN})_{6}^{4^{-}}+4 \mathrm{H}^{+}+\mathrm{O}_{2} \rightarrow 4 \mathrm{Fe}(\mathrm{CN})_{6}^{3^{-}}+2 \mathrm{H}_{2} \mathrm{O}
\end{gathered}
$$

Complete oxidation of glucose does not always occur. One might often get additional products beside $\mathrm{CO}_{2}$ and water. For example, E. Coli forms acetate, being unable to completely break down glucose, thereby limiting electricity production [11]. Rabaey et al [13] used a mixed bacterial culture and glucose, and reported the production and accumulation by the bacterial cells of fatty acids such as butyric acid. Both previously mentioned papers, however, clearly indicate that a greater efficiency in electron transfer, as well as reduced concentrations of unwanted byproducts, are achieved with a more diverse bacterial flora. This might be due to the greater ability of some bacteria to metabolize certain byproducts obtained from the oxidation of glucose.

\subsection{PROTON EXCHANGE MEMBRANE}

The Dupont Nafion-117 cation-selective membrane was used in the experimental design. The membrane was obtained from the Sigma-Aldrich company. It was advised by Dupont that this material not be used in medical applications involving permanent implantation in 


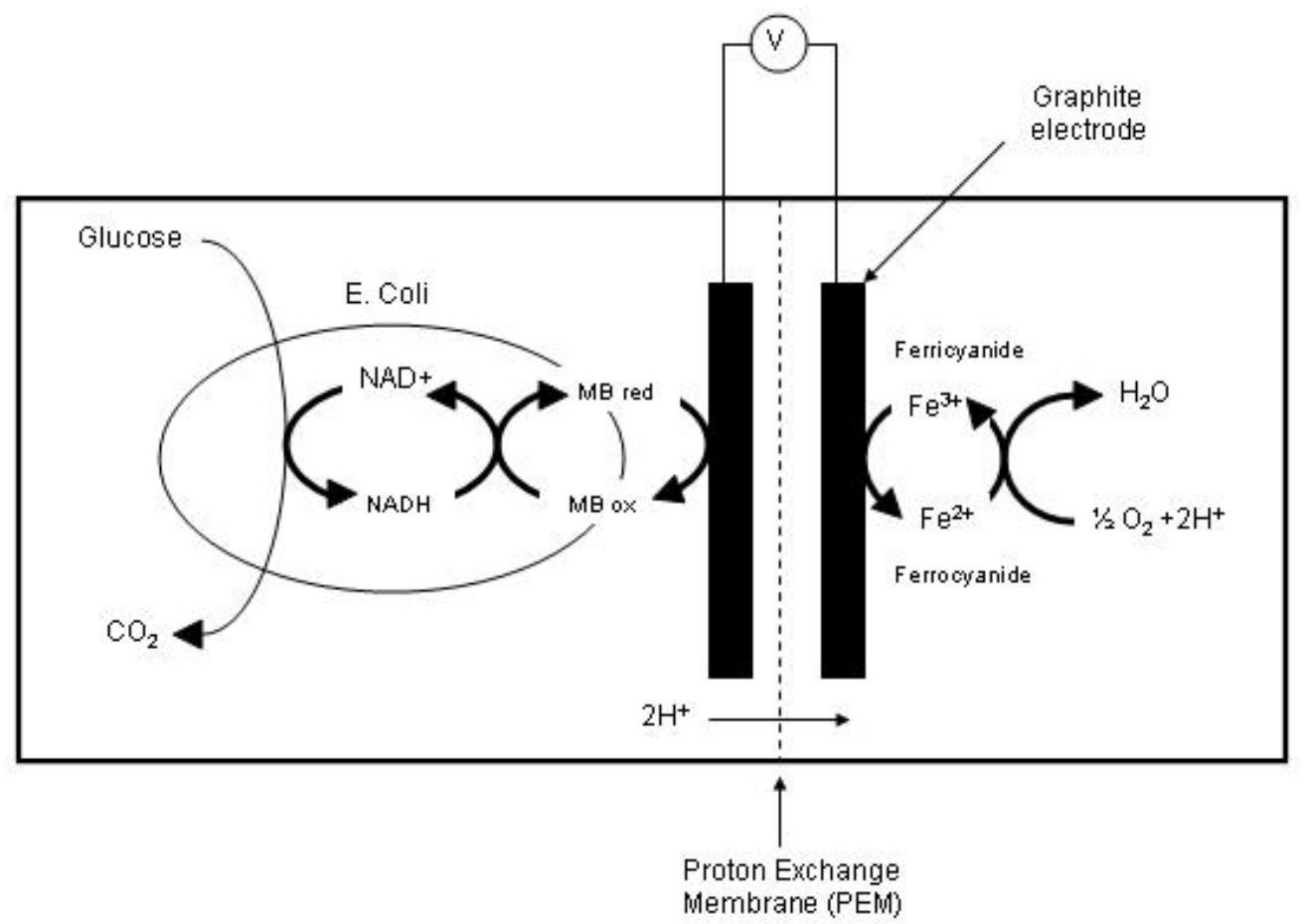

Figure 1: Illustration of a Microbial Fuel Cell with Methylene blue (MB) as the electron mediator 
the human body (Nafion Technical Information on Membranes N-111, N-112, N-1135, NE1035, N-115, NE-105, N-117). Therefore, for any potential future medical applications, an alternative PEM would need to be derived, or a biofuel cell designed that would completely eliminate the need for the membrane. The Nafion-117 membrane used in this experiment has a thickness of $0.183 \mathrm{~mm}$.

After some inquiry, it was discovered that the membrane would permit the displacement of hydrogen ions by heavier cations. The Nafion-117 membrane is, therefore, not selectively permeable to hydrogen. This fact has to be taken into careful consideration in future designs of the biofuel cell experiment.

\subsection{ELECTRON MEDIATORS}

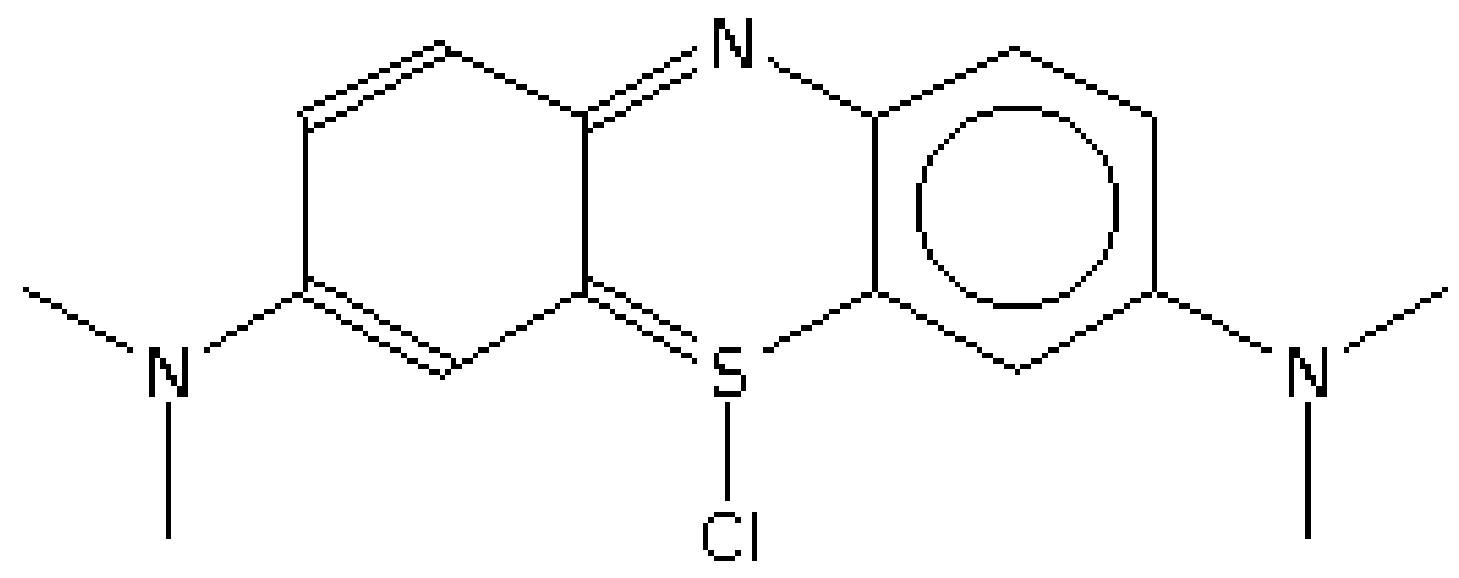

Figure 2: Methylene blue

An ideal electron mediator should [12]:

- form a reversible redox couple at the electrode;

- link to NADH and have a high negative standard reduction potential ( $\left.\mathrm{E}^{0^{\prime}}\right)$ value in order to maximize electrical energy generation; 
- be stable in both oxidized and reduced forms;

- not decompose during long-term redox recycling;

- have a mediator polarity such that the mediator is soluble in aqueous solution (near $\mathrm{pH}$ 7.0) and can be absorbed by the microbial membrane.

Methylene blue and neutral red are two commonly used electronophores in microbial fuel cells, primarily because of their minimal toxicity. Methylene blue was used in the following experiments. 


\subsection{MICROBIAL FUEL CELL EXPERIMENT I}

\subsection{INTRODUCTION}

A simple experiment was established in an attempt to validate the results and conclusions of previous papers that biofuel cells $(\mathrm{BFC})$ incorporating bacteria and electron mediators are capable of generating an electric current. In order to achieve this, a plexiglass container was constructed to house the (BFC) components. E. Coli (strain HB101) was used as the bacterial species and methylene blue as the electronophore. The BFC was capable of

producing a maximum current of $24.9 \mu \mathrm{Acm}^{-2}$ which decreased to $3.58 \mu \mathrm{Acm}^{-2}$ over the two hour period of measurement. The potential of the cell decreased from $0.326 \mathrm{~V}$ to $0.215 \mathrm{~V}$. The current was measured using an ammeter without the presence of a load. This might have contributed to rapid polarization of the electrodes and, hence, the evident decrease in the observed potential of the BFC. The method employed in this experiment for preparing the bacterial culture largely followed the procedure described in reference [11].

\subsection{APPARATUS/MATERIALS}

The following materials and solutions were used for the microbial fuel cell experiment. A special container manufactured from plexiglass was designed for purposes of this experiment. The container was used to house the BFC components.

- Graphite electrodes (approx. 5.0x4.0x0.64cm)

- Nafion-117 cation-selective membrane

- $0.01 \mathrm{M}$ methylene blue solution in 50mM potassium phosphate buffer (pH 7.0) (anode) 
- $50 \mathrm{mM}$ ferricyanide in 100mM phosphate buffer (pH 7.0) (cathode)

- Glucose $(0.55 \mathrm{mmol} / \mathrm{L})$ (anode)

- Multimeters (for measuring electric potential and current)

- Special container designed and constructed from plexiglass.

- Magnetic stirrer and stirring plate (for anode solution)

- $\mathrm{Cu}$ wires to connect to electrodes

- Bacteria (E. Coli). Approx. $2.74 \mathrm{mg} / \mathrm{mL}$ dry weight

\subsection{METHODS}

\subsubsection{Stock Solutions}

All the necessary solutions for the experiment were first prepared. They included the following:

- $1000 \mathrm{~mL}$ of $0.2 \mathrm{M}$ phosphate buffer (10.5g $\mathrm{K} \mathrm{H}_{2} \mathrm{PO}_{4}$ and $\left.21.4 \mathrm{~g} \mathrm{~K}_{2} \mathrm{HPO}_{4}\right)$

- $500 \mathrm{~mL}$ of $0.1 \mathrm{M}$ potassium ferricyanide solution

- $500 \mathrm{~mL}$ of $55 \mathrm{mM}$ glucose solution

- LB medium (10g/L bacto-tryptone, $5 \mathrm{~g} / \mathrm{L}$ yeast extract, $10 \mathrm{~g} / \mathrm{L} \mathrm{NaCl})$

- Medium I (100mM phosphate buffer [pH 7], 10g/L sodium lactate, $5 \mathrm{~g} / \mathrm{L}$ peptone, and $5 \mathrm{~g} / \mathrm{L}$ yeast extract).

Medium I and the potassium ferricyanide solutions were filtered. Ideally, all solutions to be used with bacteria should be autoclaved (sterilization process).

\subsubsection{Bacterial culture}

The method employed here primarily followed that described by Park et al [11]. The bacterial culture (E. Coli, strain HB101) was grown aerobically overnight in $100 \mathrm{~mL}$ LB medium $(10 \mathrm{~g} / \mathrm{L}$ bacto-tryptone, $5 \mathrm{~g} / \mathrm{L}$ yeast extract, $10 \mathrm{~g} / \mathrm{L} \mathrm{NaCl})$ at $37^{0} \mathrm{C}$ with vigorous agitation (250 rpm). The bacteria were harvested by centrifugation at $4000 \mathrm{rpm}$ for 15 minutes using a Sorvall Super T21 maintained at a temperature of $4^{0} \mathrm{C}$. The resting cells were washed 
twice and suspended in Medium I (100 mM phosphate buffer [pH 7], 10g/L sodium lactate, $5 \mathrm{~g} / \mathrm{L}$ peptone, and $5 \mathrm{~g} / \mathrm{L}$ yeast extract). The optical density of the bacterial suspension was then determined by spectrophotometry and used for the calculation of the cell protein concentration. An optical density of 2.03 was recorded at $660 \mathrm{~nm}$, which corresponds to a cell protein concentration of $2.74 \mathrm{mg} / \mathrm{mL}$.

\subsubsection{Biofuel Cell Design and Preparation}

A special container was designed for use as a biofuel cell case. It was constructed from plexiglass. There was, however, tremendous difficulty in making the container watertight. To achieve this all the constituent pieces would have to be cut to fit perfectly with each other. This was very difficult to accomplish, and as a result, some leaking still occurred.

The biofuel cell case is $10 \mathrm{~cm}$ long, $6.2 \mathrm{~cm}$ wide and $5 \mathrm{~cm}$ high. Each compartment has a volume of $100 \mathrm{~mL}$. The graphite electrodes had dimensions $5.5 \times 4 \times 0.64 \mathrm{~cm}$, giving a total surface area of $56.16 \mathrm{~cm}^{2}$. The PEM had an available surface area of about $9 \mathrm{~cm}^{2}$ exposed to either compartment.

The anode compartment was filled with $50 \mathrm{~mL}$ of bacterial suspension, $25 \mathrm{~mL}$ of $0.2 \mathrm{M}$ phosphate buffer, $1 \mathrm{~mL}$ glucose solution, $24 \mathrm{~mL}$ of distilled water and $0.373 \mathrm{~g}$ methylene blue. The cathode compartment was filled with $50 \mathrm{~mL} 0.2 \mathrm{M}$ phosphate buffer and $50 \mathrm{~mL} 0.1 \mathrm{M}$ potassium ferricyanide solution. The final concentrations desired were $0.55 \mathrm{mM}$ glucose solution, $50 \mathrm{mM}$ potassium ferricyanide solution, $0.01 \mathrm{M}$ methylene blue, and $50 \mathrm{mM}$ and $100 \mathrm{mM}$ potassium phosphate buffer at the anode and cathode respectively.

In this experiment, a nitrogen atmosphere was not provided at the anode compartment and aeration of the cathode compartment was not performed as described in Reference [12]. These two methods have been employed in previous papers in an attempt to maximize current output. The biofuel cell was connected in parallel with a multimeter, and values of voltage and current were measured over a period of about 2 hours.

At the end of the two hour period, the biofuel cell and all its components were then thoroughly cleaned, and the compartments replaced with distilled water. The potential between the electrodes was recorded. The biofuel cell was also tested to determine if an 
electric potential could be observed in the absence of the bacteria.

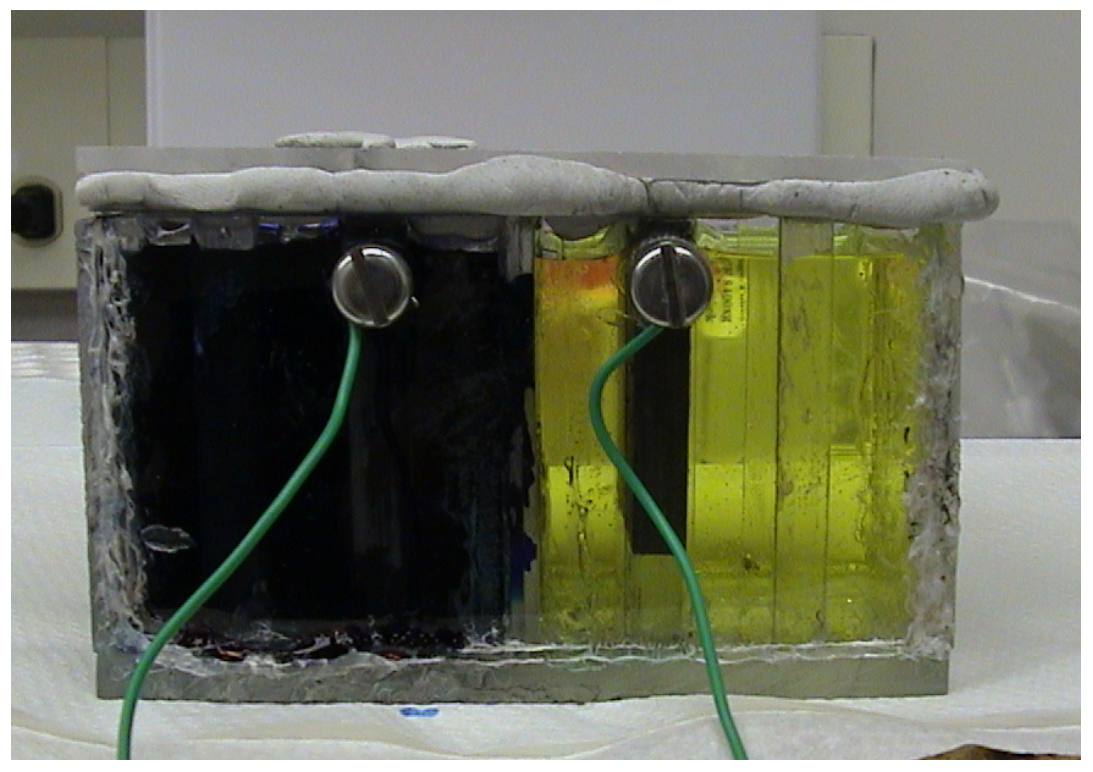

Figure 3: Biofuel Cell Setup (Front View)

\subsection{OBSERVATIONS}

Upon adding the glucose solution to the anode compartment, containing all solutions, including the bacteria, measurements of current and voltage were made. This was done using a multimeter. Some difficulty was experienced in making these measurements, as the values tended to vary rather quickly. There was a rapid decrease in the values of voltage and current which lasted over a minute, after which the numbers began to stabilize. It was observed that this occurred every time the multimeter was turned on, or switched between measuring current and voltage. As a result, there was some difficulty in making precise measurements.

When the biofuel cell container was filled with distilled water, a potential was not observed between the electrodes. When the fuel cell was prepared in the absence of bacteria, a potential was observed and current was generated. Both the potential and the current, however, were smaller than in the instance of bacterial presence, by an order of magnitude. 
At the cathode, small bubbles could be observed, indicating the occurence of a chemical reaction.

\subsection{RESULTS}

The biofuel cell devised in this experiment generated an electric current. Measurements of electric potential and current were measured over a 2 hour period. Graphs illustrating changes in current and voltage over time are indicated in Figure 4.

Both the current and voltage decreased over the 2 hour period. The decreasing voltage might be attributed to polarization of the electrodes. It is possible that on maximum current output, the electrodes become polarized and the voltage fall, requiring some time to recover. Internal resistances inherent to the system could not be determined. One would, however, expect an increase in the internal resistance of the MFC due to:

- Diffusion of hydrogen ions in the anode compartment, reducing the rate of transfer across the PEM.

- Formation of products which could coat the electrode or the proton exchange membrane.

- Cells dying over time as a result of changes in $\mathrm{pH}$.

- Reduced availability of electrons for transfer to the electrodes as a result of decreasing concentrations of glucose.

- denaturation of the electron mediator

- increasing transfer of electrons to molecular oxygen

When water was placed in the electrode compartments, no current or potential was generated. In the biofuel cell preparation without bacteria, however, a small current and potential were recorded. A current of $0.05 \mathrm{~mA}$ and potential of $0.02 \mathrm{~V}$ were recorded upon initial measurement. Both these values decreased over time. 

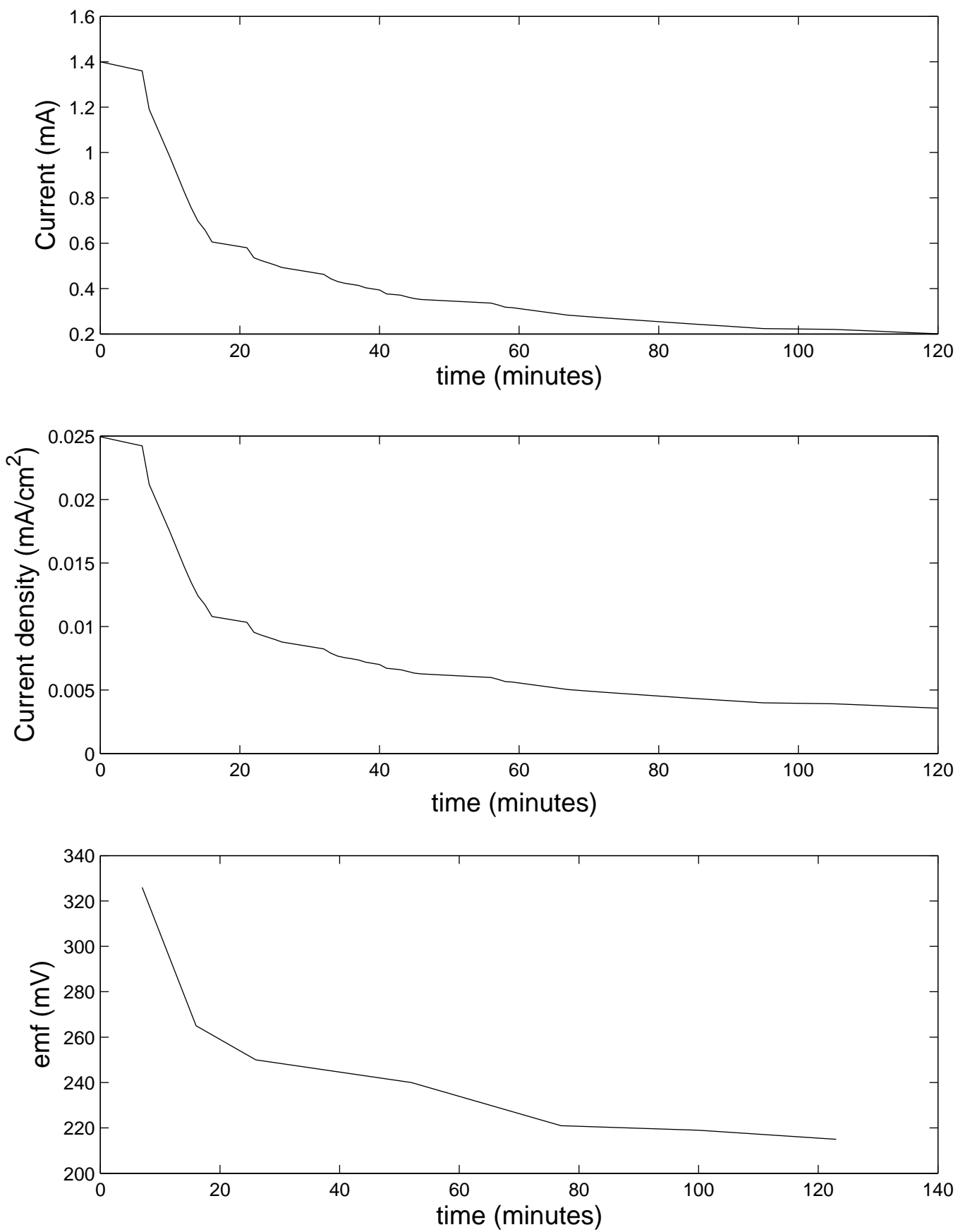

Figure 4: Measurements of current, current density and electromotive force acquired from the microbial fuel cell 


\subsection{DETERMINING THE MAXIMUM POSSIBLE POWER OUTPUT}

The equivalent current of the rate of methylene blue reduction by E. Coli can be calculated by the following equation [14]:

$$
I=k c n F
$$

where $\mathrm{k}=$ rate of reduction $\left(\mathrm{mol} g^{-1} s^{-1}\right), \mathrm{c}=$ dry weight of organism $(\mathrm{g}), \mathrm{n}=$ number of electrons transferred per molecule of mediator and $\mathrm{F}=$ Faraday constant $\left(96500 \mathrm{C} \mathrm{mol}^{-1}\right)$.

\subsection{CALCULATION OF CURRENT OUTPUT UNDER OPTIMAL CONDITIONS}

$\mathrm{k}=4.16 \mu \mathrm{mol} g^{-1} s^{-1}$ - Rate of reduction of methylene blue by E. Coli [14]

$\mathrm{c}=0.274 \mathrm{~g}$ (obtained from spectrophotometric measurements)

$\mathrm{n}=2$ electrons/molecule of methylene blue (transfer of a hydride ion from NADH/NADPH)

Half-cell potential of methylene blue $=+0.011 \mathrm{~V}$

Half-cell potential of ferricyanide $=+0.360 \mathrm{~V}$

E.M.F of biofuel cell $=+0.349 \mathrm{~V}$

- Current can be calculated as follows $(\mathrm{I}=\mathrm{kcnF})$ :

$I=\left(4.16 * 10^{-6}\right)(0.274)(2)(96500) A=0.219 A$

- Current density can be calculated as follows:

$i=I / A=0.219 A / 56.16 \mathrm{~cm}^{-2}=3.96 * 10^{-3} \mathrm{Acm}^{-2}=3.96 \mathrm{mAcm}^{-2}$

The above calculations are made under the assumption that there is uniform distribution

of the dye, and methylene blue among the bacteria and that there is an even distribution of the bacterial population across the graphite electrode surface. Based on these calculations, one would expect a maximum current density of $3.96 \mathrm{~m} \mathrm{Acm}^{-2}$. A maximum current density 
of only $24.9 \mu \mathrm{Acm}^{-2}$ was obtained in our experiments. There is evidently a low efficiency in the rate of electron transfer to the electrodes.

\subsection{CONCLUSIONS}

Biofuel cells incorporating E. Coli as the bacteria and methylene blue as the electron mediator do generate electricity. Current densities as high as $24.9 \mu \mathrm{Acm}^{-2}$ were recorded, which gradually decreased over the course of the experiment. A maximum electric potential of $0.326 \mathrm{~V}$ was recorded, which decreased to $0.215 \mathrm{~V}$ by the end of the experimental period. Current densities decreased from $24.9 \mu \mathrm{Acm}^{-2}$ to $3.58 \mu \mathrm{Acm}^{-2}$ within the two hour period. The current densities recorded are similar to values previously reported in the literature. However, recently, current densities as high as $1.5 \mathrm{mAcm}^{-2}$ have been reported [13],[15]. 


\subsection{MICROBIAL FUEL CELL EXPERIMENT II}

\subsection{INTRODUCTION}

A second experiment was performed to investigate current generation in microbial fuel cells. This time, a microbial fuel cell kit was purchased from the National Center of Biotechnology Education (NCBE) at the University of Reading, United Kingdom. The toolkit consisted of several Perspex pieces, a proton exchange membrane (PEM), rubber gaskets and screws and bolts for assembly. A similar procedure was utilized to the one described previously for preparing the bacterial culture. The working volume of the NCBE microbial fuel cell is only $10 \mathrm{~mL}$ per compartment, as opposed to $100 \mathrm{~mL}$ per compartment in the original plexiglass case described in the first experiment (Microbial Fuel Cell Experiment I).

Another difference between the first experiment and the second is the fact that a load was included in the design of the circuit. A fault of the previous experiment was the fact that a resistance was not used with the MFC. As a result, polarization of the electrode might have occurred, leading to inaccurate results.

Three resistances were used during the measurement of the current output of the MFC. For the $50 \Omega$ resistor, a maximum current density of $2.4 \mu \mathrm{Acm}^{-2}$ was measured, which decreased to $1.2 \mu \mathrm{Acm}^{-2}$ over the two hour period of measurement.

\subsection{APPARATUS/MATERIALS}

The apparatus used for this experiment was acquired from the National Center of Biotechnology Education (NCBE) at the University of Reading in the United Kingdom. Each biofuel 
cell kit included the following:

- Woven graphite felt electrodes $\left(0.45 \mathrm{~m}^{2} / \mathrm{g}\right.$ available surface area)

- 4 pieces cut from 5mm thick Perspex sheet

- 2 rubber gaskets

- an ion exchange membrane

- screws and bolts to hold the pieces together

In the final assembled cell, each compartment has a volume of $10 \mathrm{~mL}$.

\subsection{METHOD}

A similar procedure to that described in the previous chapter for preparing the bacterial culture was performed (Microbial Fuel Cell Experiment I). E. Coli HB101 was cultured aerobically overnight in $50 \mathrm{~mL}$ of $\mathrm{LB}$ medium at $37^{0} \mathrm{C}$ with vigorous agitation $(250 \mathrm{rpm})$ for 20 hours. All solutions were prepared as described in the previous chapter. The bacteria were harvested by centrifugation at 4000 rpm for 15 minutes using a Sorvall Super T21 maintained at a temperature of $4^{0} \mathrm{C}$. The resting cells were washed twice and suspended in Medium I (100 mM phosphate buffer [pH 7], 10g/L sodium lactate, 5g/L peptone, and 5g/L yeast extract). By spectrophotometry, the cell concentration was determined to be $2.60 \mathrm{mg} / \mathrm{mL}$. The solutions were placed at the cathode and anode in the desired concentrations. The final concentrations desired were $0.55 \mathrm{mM}$ glucose solution, $50 \mathrm{mM}$ potassium ferricyanide solution, $0.01 \mathrm{M}$ methylene blue, and $50 \mathrm{mM}$ and $100 \mathrm{mM}$ potassium phosphate buffer at the anode and cathode respectively.

Measurements of voltage were made across three resistors of resistances $50 \Omega, 100 \Omega$, and $500 \Omega$. Currents were calculated from these measurements using Ohm's Law. Woven graphite felt electrodes were used in this experiment. The electrodes had dimensions $2.5 \mathrm{~cm} x 3.8 \mathrm{~cm}$ and a mass of $0.03 \mathrm{~g}$. The specific surface area of the graphite felt electrodes is $0.45 \mathrm{~m}^{2} / \mathrm{g}$, corresponding to a total surface area of $0.0135 \mathrm{~m}^{2}\left(135 \mathrm{~cm}^{2}\right)$. 


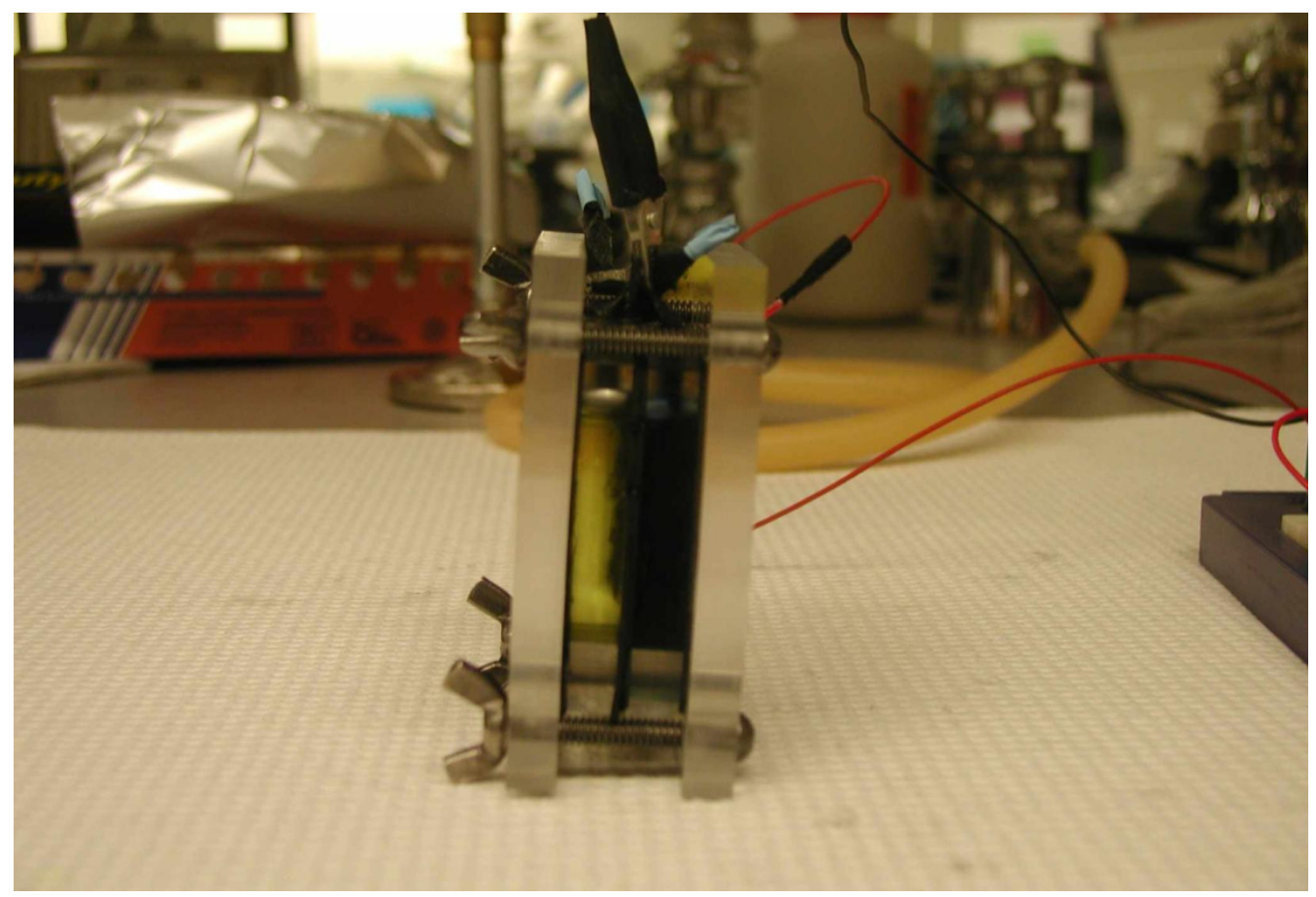

Figure 5: Microbial fuel cell experimental setup to test whether E. Coli is able to generate an electrical current. The apparatus was assembled from parts acquired in a toolkit from the National Center of Biotechnology Education (NCBE). 


\subsection{RESULTS}

An initial slight increase in the current was observed after which there was a rapid decrease in the current output. After about an hour, the current began to stabilize. The rate at which the current output decreased was much slower in this experiment compared to the first (MFC Experiment 1), where a load was not used with the MFC.

Table 1: Maximum and minimum current densities $\left(\mu \mathrm{A} / \mathrm{cm}^{2}\right)$ for the $50 \Omega, 100 \Omega$, and $500 \Omega$ resistors.

\begin{tabular}{|rrrr|}
\hline$I$ & 50 Ohms & 100Ohms & 500Ohms \\
\hline $\max$ & 2.4 & 2.1 & 1.9 \\
$\min$ & 1.2 & 1.2 & 1.1 \\
\hline
\end{tabular}

Figure 7 compares the current densities acquired from the MFCs prepared in Experiments 1 and 2. The current output is much larger in Experiment 1 than in Experiment 2, perhaps reflecting limitations in the setup of the latter. The smaller volume and the proximity of the electrodes to the proton exchange membrane (PEM) might have been contributing factors. Due to the rather small size of the MFC assembled in Experiment 2, it proved difficult to prevent the woven graphite felt electrodes from adhering to the PEM. There was also limited exposure of the cathode compartment to the air, which would greatly inhibit the oxidation of ferrocyanide to ferricyanide. Inhibition of this reaction would significantly affect the rate of electron transfer and thus the current.

\subsection{CONCLUSION}

This experiment showed, as in the previous, that an electrical current can be generated by E. Coli, with methylene blue as the electron mediator. A maximum current density of $2.4 \mu \mathrm{Acm}^{-2}$ was measured, which decreased to $1.2 \mu \mathrm{Acm}^{-2}$ in the presence of a $50 \Omega$ load. 

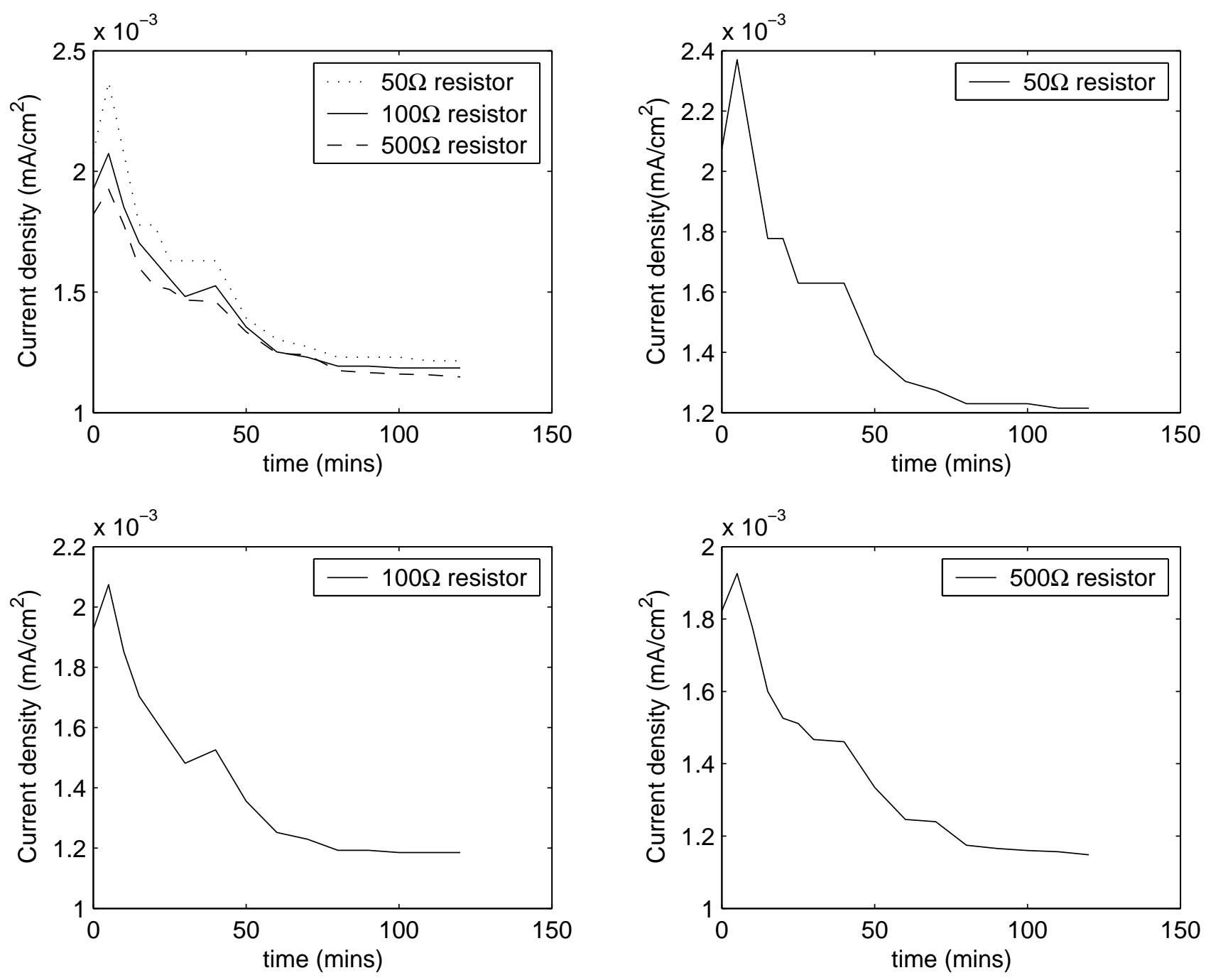

Figure 6: Current densities from microbial fuel cell experiment 2. Current density decreased rapidly over the first hour of measurement after which a gradual levelling off could be observed. Effects of polarization, increased electron transfer to molecular oxygen and cell death could be attributed to these observations. 


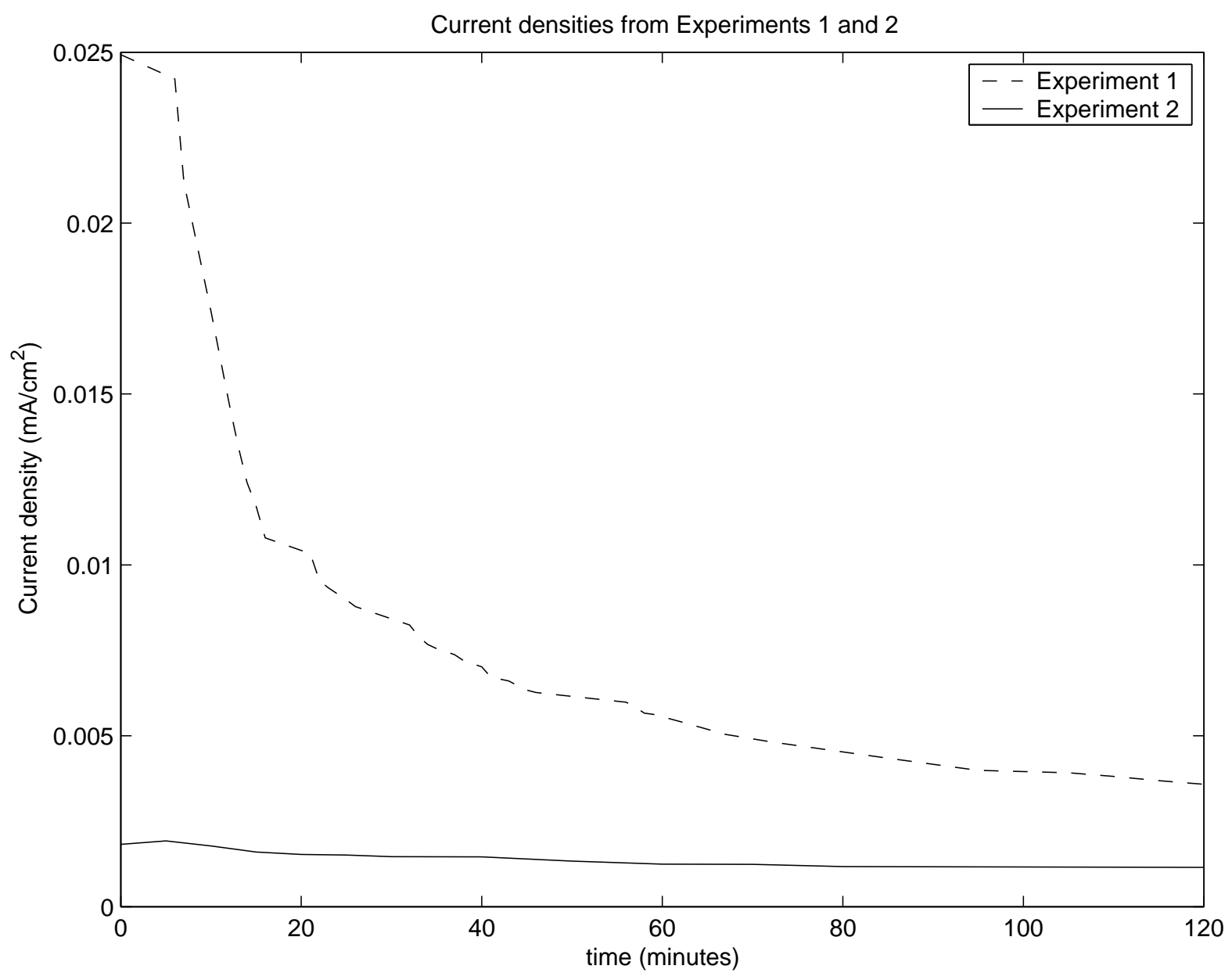

Figure 7: Current densities from Microbial Fuel Cell (MFC) Experiments 1 and 2. Experiment 1 lacked a load. In Experiment 2, however, a $500 \Omega$ load was used. The results from Expt. 2 seem to suggest that the effects of polarization are reduced when the MFC is placed in series with a sufficiently large resistance. 


\subsection{DISCUSSION OF MFC EXPERIMENTS}

The results seem to show that there is an electrical potential and current generation associated with the bacterial oxidation of glucose. The current density produced was comparable to literature values [7],[12]. However, very recent publications have shown that dramatic increases in the current output are possible through various modifications of the MFC [11],[13],[15].

The experiments described were very basic in their set-up. The E. Coli was grown under aerobic conditions and the anode compartment maintained in an oxygen atmosphere. The presence of oxygen at the anode compartment would significantly affect the current output. Molecular oxygen is the last electron acceptor in the electron transport chain. Its presence in the anode compartment would mean that a siginificant number of electrons would be transferred to oxgyen, as opposed to being transferred to methylene blue molecules and subsequently to the electrode. One would, therefore, expect a reduced current output because of the reduced availability of electrons under these conditions. If a nitrogen/carbon dioxide atmosphere were maintained at this electrode, a higher current output would be expected. How much higher cannot be exactly ascertained.

In these experiments, aeration by bubbling of air through the cathode solution was neglected. As a result, the rate at which oxygen is reduced to water would be very slow. This would have a direct effect on current output - a lower current output would be expected than if aeration had occurred.

The distance between the proton exchange membrane (PEM) and the electrodes might have also been a factor, as it is ideal for the electrode to be as close to the PEM as possible for rapid transfer of hydrogen ions accross the membrane. This might have been true more in

the instance of the fabricated plexiglass case (Experiment 1), where the graphite electrodes 
were a little over $1 \mathrm{~cm}$ away from the PEM. It would be difficult to determine to what extent distance affects rate of diffusion of hydgrogen ions across the membrane.

There was a very evident instability in the measurements of the open circuit voltage and the current recorded in the first experiment (Experiment 1). The instability was characterized by a rapid reduction in both these parameters (on the order of $\mathrm{mV}$ for the potential and $\mu \mathrm{A}$ for current), followed by a point where an equilibrium state was achieved. This might have been a result of connection of the multimeter directly to the electrodes, without including a load (resistance). The change in the values of electric potential might have also been the result of temperature and concentration changes incurred in the biofuel cell. A definitive reason for this observation has not been determined. Electrode polarization, however, might have been the primary contributor. The rate of decrease of current over time was much less in the second experiment (Experiment 2), where a load was used, compared to the first. The magnitude of the current density is also much smaller.

Under optimal conditions, the microbial fuel cell (MFC) of Experiment 1 should have yielded a current density of $3.96 \mathrm{mAcm}^{-2}$ (see MFC Experiment 1). Therefore, a lot of work is still left to be done in order to maximize the current outputs of biofuel cells. 


\subsection{LEUKOCYTE BIOFUEL CELL}

\subsection{INTRODUCTION}

In 1998, a Swiss team reported their findings in the journal Nature that electron currents are generated by NADPH oxidase (a membrane-bound enzyme) in human eosinophil granulocytes [20]. The medical team, from Geneva's University Hospital, was the first to show that white blood cells can produce electrogenic currents across their extracellular membrane. The finding provided some new insight into how the human body fights microbes.

Electron transport is generally not observed in the plasma membrane of eukaryotic cells, except in phagocyte NADPH oxidase. It has been found that the enzyme is responsible for the generation of reactive oxygen species, superoxide $\left(\mathrm{O}_{2}^{-}\right)$, through electron transfer from NADPH to extracellular oxygen. In a process called a 'respiratory burst', superoxide is formed, and used as a means by which the blood phagocytes attack and destroy microbes.

Electron-transfer currents should depend on the following:

- The presence of the cytosolic electron donor (NADPH).

- A functional electron-transport chain (NADPH oxidase).

- The presence of an extracellular electron acceptor (molecular oxygen).

Since the Nature article published by the Swiss medical team, a number of other articles have supported the idea that electrogenic currents do exist across the plasma membrane of white blood cells [16], [17], [18], [19]. Based on these recent publications, an attempt was made to design a BFC, which utilizes white blood cells as electron donors as opposed to microbial organisms such as E. Coli. A similar principle would be employed to that of the MFC. The hope would be to promote the transfer of electrons, via the NADPH oxidase 
complex, to the anode.

\subsection{METHOD}

\subsubsection{Biofuel cell}

The apparatus used in this experiment was acquired from the National Center of Biotechnology Education (NCBE) at the University of Reading [9].

\subsubsection{Acquisition of neutrophils and B and T lymphocytes}

A blood volume of $27.5 \mathrm{~mL}$ was obtained and placed in a $50 \mathrm{~mL}$ tube. The tube was then filled up to $50 \mathrm{~mL}$ with phosphate-buffered saline solution. $15 \mathrm{~mL}$ of Ficoll-Paque ${ }^{T M}$ plus was placed into each of two (2) 50mL tubes. The blood-phosphate buffer suspension was then transferred by pipette into each of the two tubes in equal volumes $(25 \mathrm{~mL}$ transferred into each of the two tubes filled with Ficoll-Paque ${ }^{T M}$ plus). Centrifugation at 2000rpm for 25 minutes was then performed, after which the neutrophil layer and the B and $\mathrm{T}$ cell layer were aspirated and placed into two separate $50 \mathrm{~mL}$ tubes. The tubes were subsequently filled to $50 \mathrm{~mL}$ with the phosphate-buffered saline. The cells were centrigued at 1700rpm for 15 minutes and the supernatant removed. The final cell volume was then made up to $10 \mathrm{~mL}$ in phosphate-buffered saline. A cell count was performed under a light microscope using a hematocytometer.

\subsubsection{Preparation of Biofuel Cell}

The cathode solution was made from $5 \mathrm{~mL}$ of $0.1 \mathrm{M}$ potassium ferricyanide and $5 \mathrm{~mL}$ phosphatebuffered saline ( $\mathrm{pH}$ 7.4). The ferricyanide solution and the cell suspension were placed in the cathode and anode compartments respectively. $10 \mu \mathrm{L}$ each of $500 \mathrm{ng} / \mathrm{mL}$ calcium ionomycin and 5ng/mL phorbol-12-myristate-13-acetate (PMA) were used to activate the white blood cells at the anode. PMA is a known NADPH oxidase activator. Ionomycin is used concurrently, increasing intracellular calcium. 
The BFC was connected within a circuit and measurements of voltage across a resistor were made, from which current can be determined by Ohm's Law. The above described method was used to investigate electricity generation by both neutrophils and the $\mathrm{B}$ and $\mathrm{T}$ lymphocytes. A control was setup where cells were excluded from the preparation. Measurements were made over a two hour period.

The effects of the antioxidant N-acetyl-L-cysteine (NAC) and a non-ionic detergent, Igepal, were investigated, in an effort to gain some insight into the mechanism by which electrons are transfered from the cells to the electrode. One would expect the current produced by the cells to decrease in the presence of both of these agents, if it is assumed that either superoxide or NADPH oxidase plays a direct role in the electron transfer process. NAC should reduce or extinguish the effect of the superoxide, while Igepal should denature the cellular membrane, theoretically destroying the functional NADPH oxidase enzyme complex.

\subsection{OBSERVATIONS}

Very small, ubiquitous bubbles could be seen at both the anode and the cathode. After some time, a greenish blue tint could be seen at the cathode. These observations might be an indication that reactions are occurring at both these electrodes. The voltage across the resistor seemed to be much more easily and drastically affected by movement of the BFC employing B/T cells compared to neutrophils. The neutrophil currents were relatively stable inspite of disturbances to the BFC. An explanation for this has not yet been determined.

At the end of every experimental trial, it was observed that addition of the colorless anode solution to the yellow cathode solution created a deep blue-green solution. It is, therefore possible that some other redox reactions are occurring, which would ultimately lead to background currents in the BFC. The nature of these redox reactions have not yet been established. If they do exist, then the magnitude of these background currents needs to be determined. 


\subsection{RESULTS}

The current densities acquired from the biofuel cells employing leukocytes to generate electricity are illustrated in Figure 8. Neutrophils seem to perform better than E. Coli, in that they are able to generate a more stable electrical current without the use of electron mediators or an anaerobic atmosphere. The current output from the B and $\mathrm{T}$ cells increased over time, eventually surpassing the maximum current produced by the neutrophils. In the absence of blood cells, the current output was greatly reduced.

In comparing the current generation between Expt.3 and Expt.4 (first and second leukocyte BFC experimental trials) it was observed that the currents obtained for the neutrophils in both trials are very similar (Figure 9). A great difference in the currents generated over time, however, is observed in the case of the $\mathrm{B} / \mathrm{T}$ cells.

The neutrophil count and B/T cell count in Expt 3 were $1.95 \times 10^{6} / \mathrm{mL}$ and $4.39 \times 10^{6} / \mathrm{mL}$ respectively. In Expt 4, the neutrophil count and B/T cell count $1.81 \times 10^{6} / \mathrm{mL}$ and $0.54 \times 10^{6} / \mathrm{mL}$ respectively. Expected current outputs can, therefore, be calculated.

DeCoursey et al [17] reported that average electrogenic currents across the cell membranes of neutrophils were about -2.3pA per cell. Based on this value and the cell counts,

one would expect current densities of about $2.36 \mu \mathrm{Acm}^{-2}$ for Expt 3 and $3.78 \mu \mathrm{Acm}^{-2}$ for Expt 4. With a $100 \Omega$ resistor, current densities for the neutrophils were slightly lower than the expected values at around $1.9 \mu \mathrm{Acm}^{-2}$ for Expt 3 and $2.2 \mu \mathrm{Acm}^{-2}$ for Expt 4 .

Addition of NAC did not seem to have a very great effect on the BFC's current output (Figure 10). In fact, a slight increase in the current was observed. Upon addition of the non-ionic detergent, Igepal, however, a decrease in the current was observed, followed by an increase in current. Sizeable currents were observed in the absence of the white blood cells, which suggests that other redox reactions might be occurring (Figure 12).

\subsection{CONCLUSION}

These experiments seem to suggest that white blood cells, specifically, neutrophils and B and $\mathrm{T}$ cells generate electrical currents when integrated into biofuel cells. The neutrophils seemed 

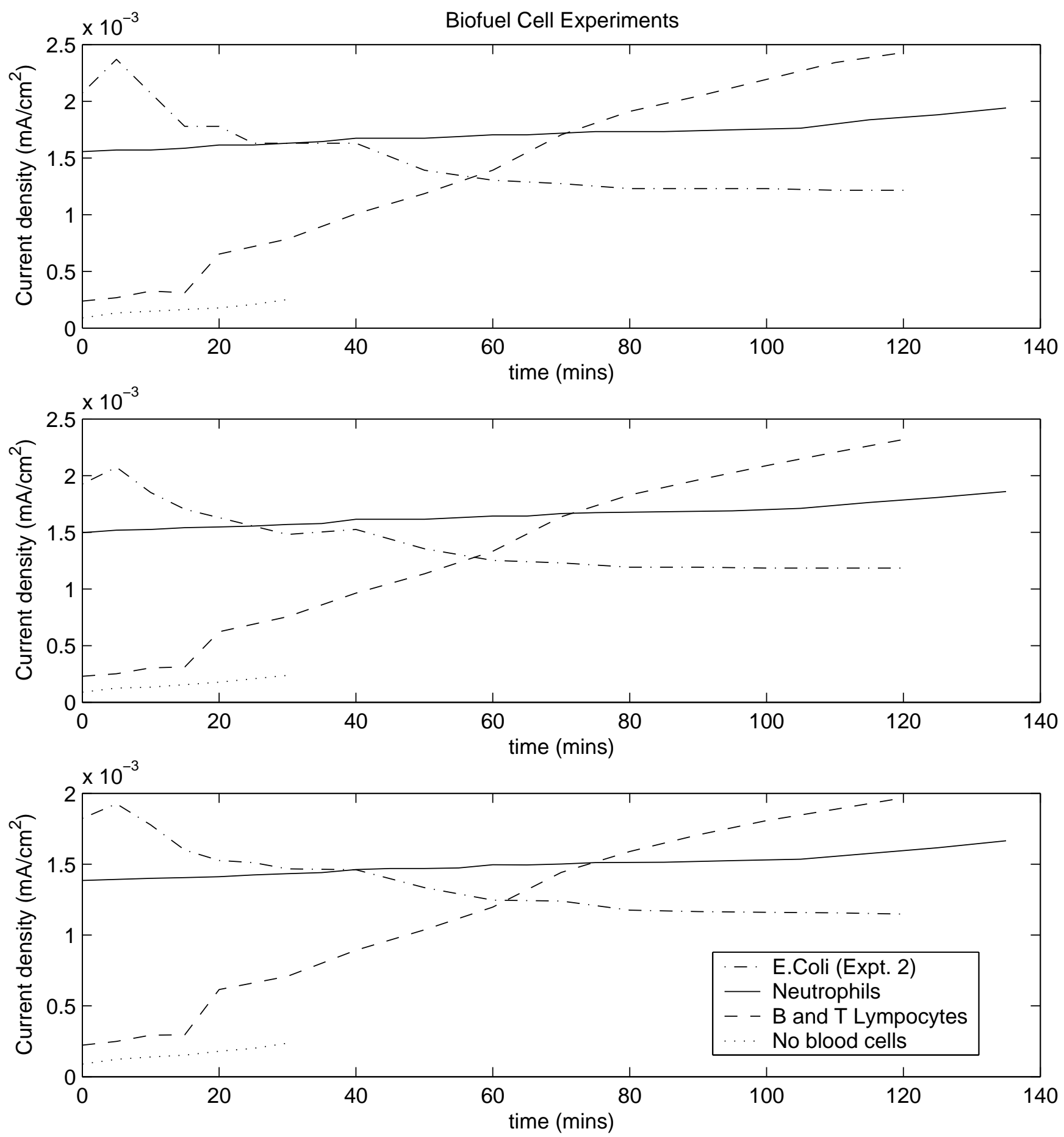

Figure 8: Comparison of current densities from Experiment 2 (MFC Experiment II) and Experiment 3 (first leukocyte biofuel cell experiment). $50 \Omega$ resistor (Top); $100 \Omega$ resistor (Middle); $500 \Omega$ resistor (Bottom). 
Table 2: Maximum and minimum neutrophil current densities $\left(\mu \mathrm{A} / \mathrm{cm}^{2}\right)$ for the $50 \Omega, 100 \Omega$, and $500 \Omega$ resistors (Experiment 3).

\begin{tabular}{|rrrr|}
\hline$I$ & 50Ohms & 100Ohms & 500Ohms \\
\hline $\max$ & 1.9 & 1.9 & 1.7 \\
$\min$ & 1.6 & 1.5 & 1.4 \\
\hline
\end{tabular}

Table 3: Maximum and minimum neutrophil current densities $\left(\mu \mathrm{A} / \mathrm{cm}^{2}\right)$ for the $100 \Omega$ resistor (Experiment 4).

\begin{tabular}{|rr|}
\hline$I$ & $1000 h m s$ \\
\hline $\max$ & 2.2 \\
$\min$ & 1.6 \\
\hline
\end{tabular}



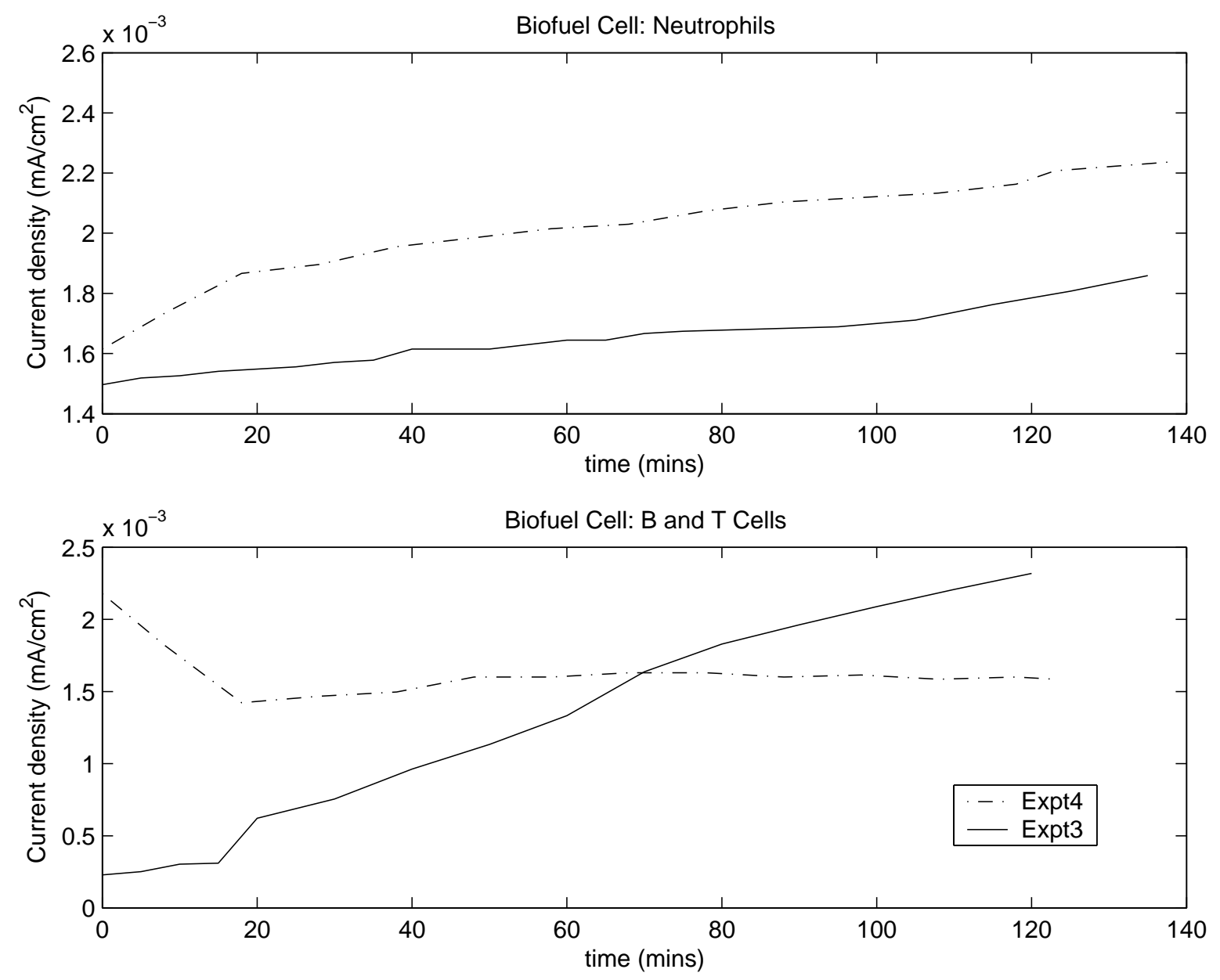

Figure 9: Current densities acquired from biofuel cell. Current densities were acquired using a circuit with a $100 \Omega$ resistor. Differences can be seen in the current generated between the first and second leukocyte biofuel cell trials (Expt 3 and Expt 4 respectively). 


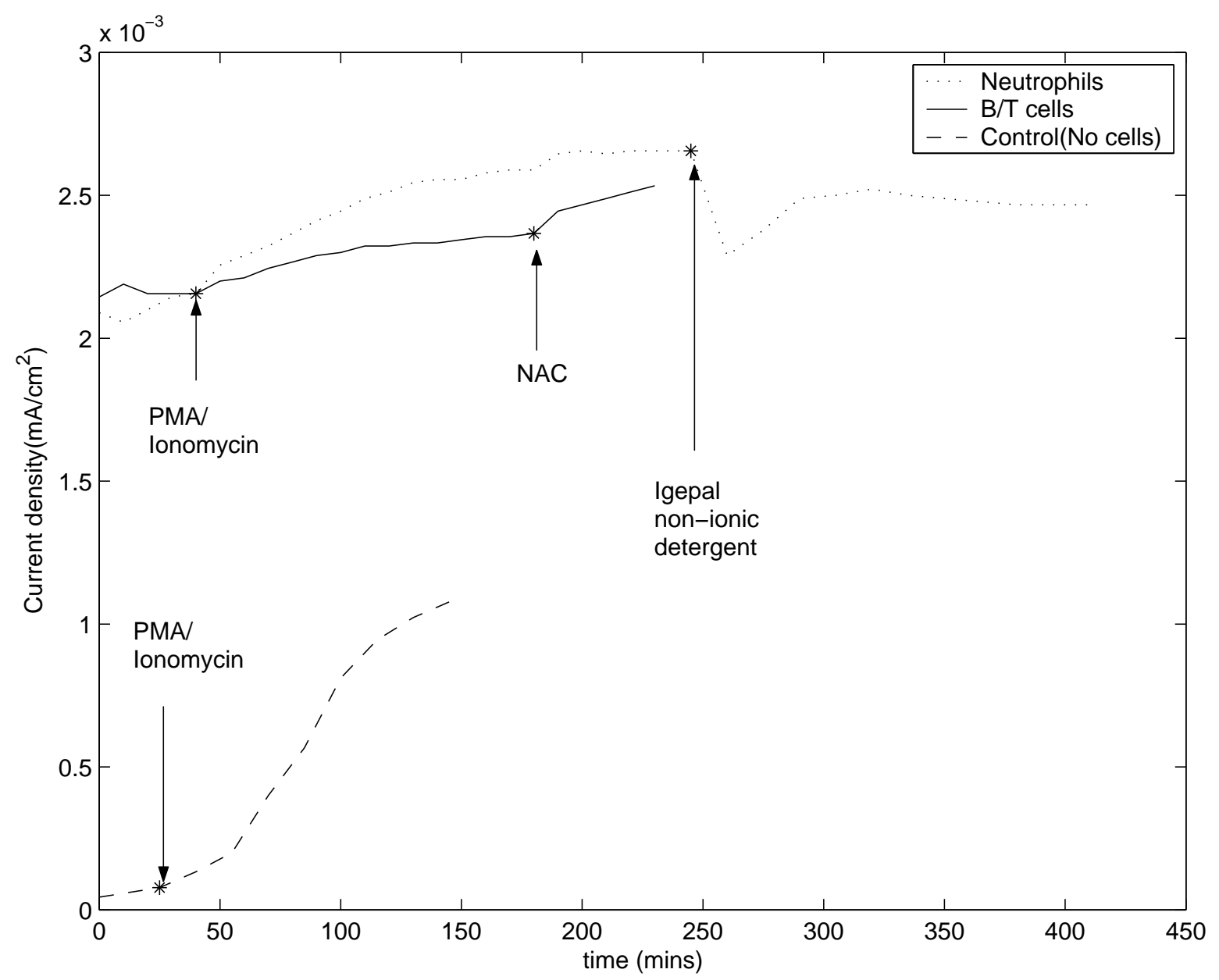

Figure 10: Current densities acquired from biofuel cell (Experiment 5). Current densities were acquired using a circuit with a $100 \Omega$ resistor. The antioxidant, NAC, increased the current slightly, however, a drop occurs upon addition of the non-ionic detergent, Igepal. In the instance of the control (no cells), an increase in the current density was observed on addition of PMA/ionomycin. This might be due to some cells remaining even after the biofuel cell container was washed out. 


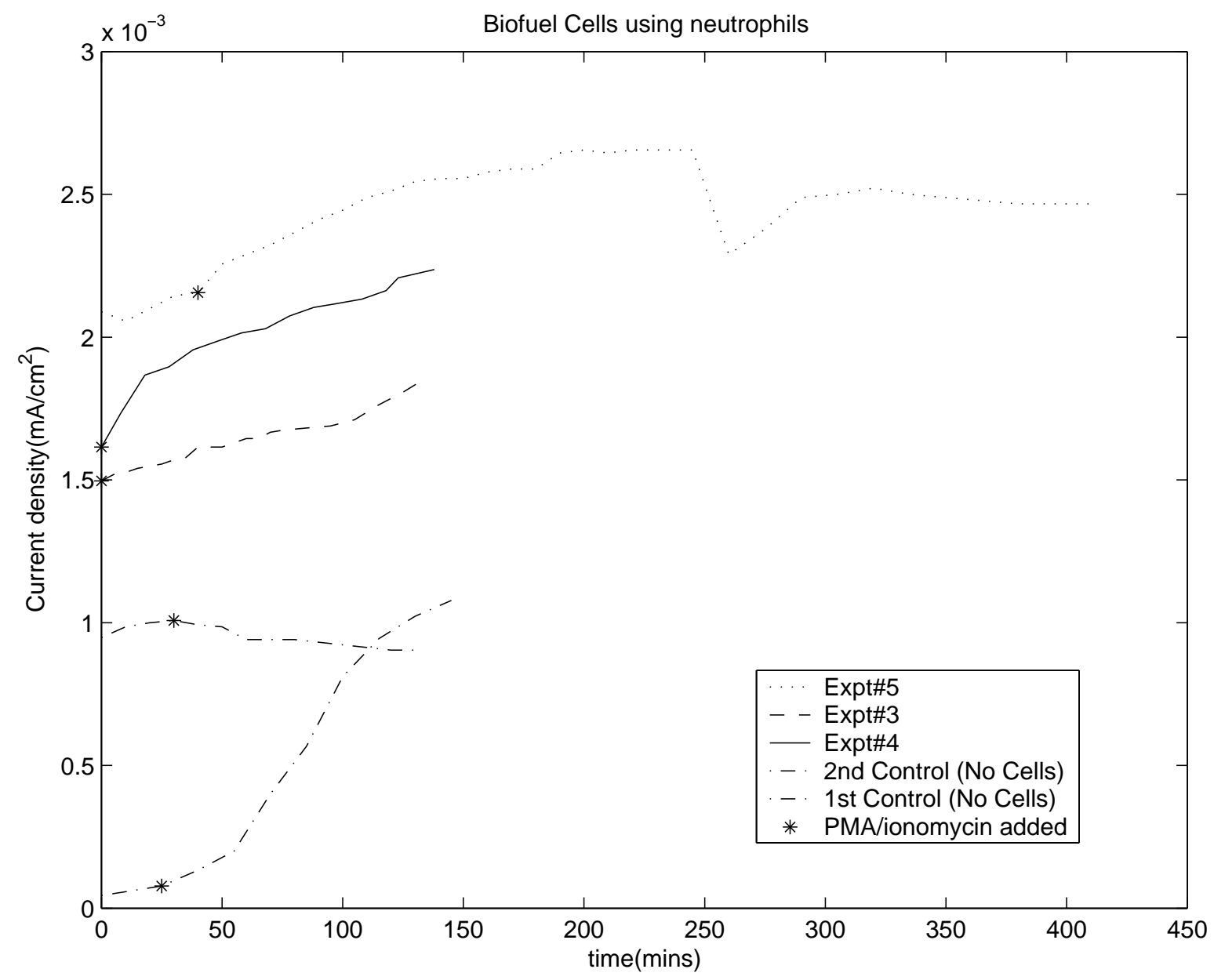

Figure 11: Comparison of the current densities acquired from the leukocyte biofuel cell in three different trials (Experiments 3, 4 and 5). These were in turn compared to an additional experimental trial without cells included in the preparation. 


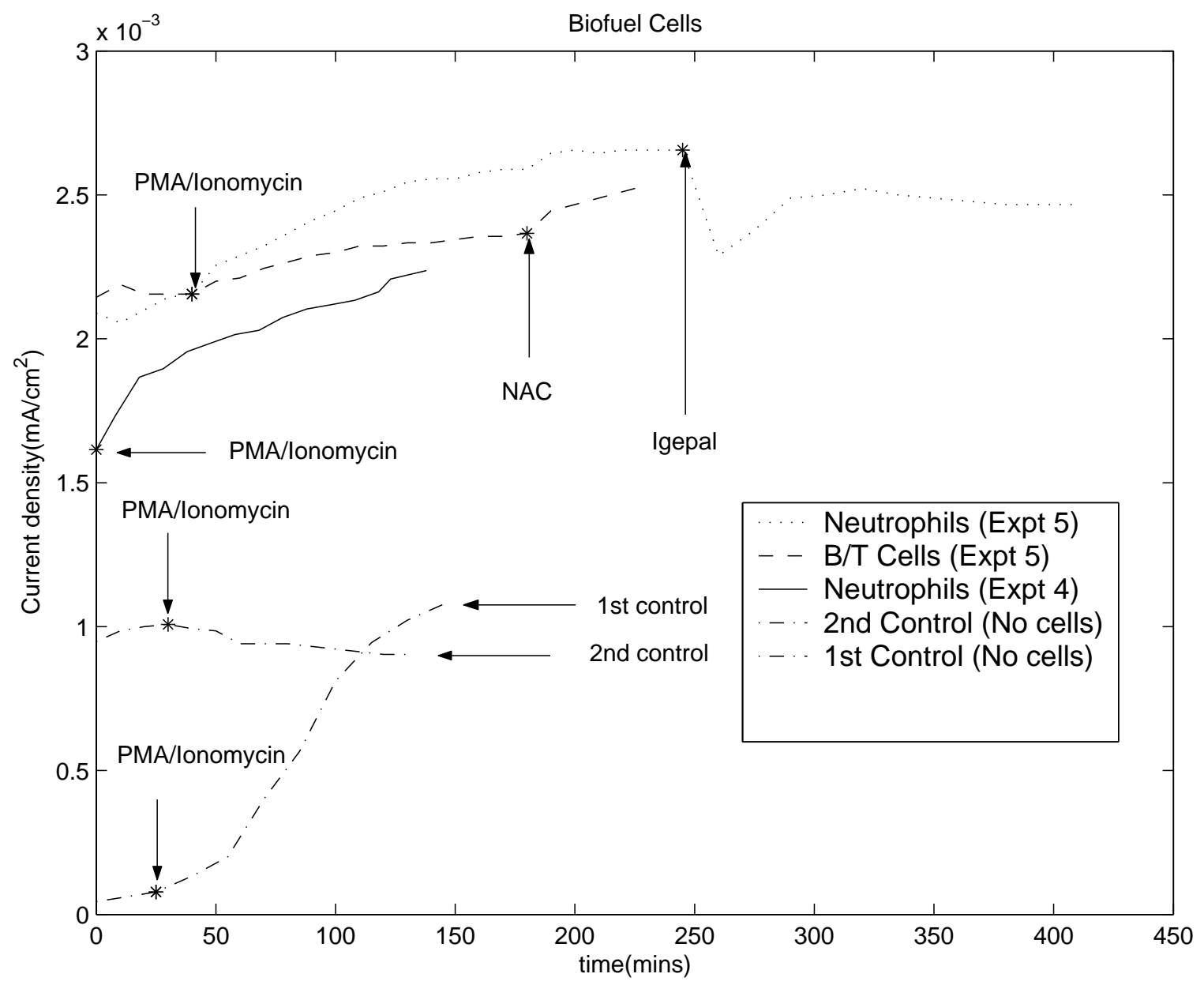

Figure 12: Current densities acquired from the leukocyte biofuel. 
to be able to generate a fairly stable current, normally between $1.4 \mu \mathrm{Acm}^{-2}$ and $2.7 \mu \mathrm{Acm}^{-2}$. The ionic detergent, Igepal, decreased currents, though not completely, suggesting the the white blood cells might play a role in the observed currents generated by the biofuel cell.

In the absence of cells, however, a sizeable current was still observed. It is, therefore, reasonable to conclude that there may be other redox reactions contributing to the observed current.

This observation raises some important questions as to whether the white blood cells do in fact contribute to the observed electrical currents and to what extent these contributions are made. 


\subsection{DISCUSSION OF LEUKOCYTE BFC EXPERIMENTS}

The leukcoyte-based biofuel cells described demonstrated rather stable current outputs over the two hour period of measurement. The exact mechanism by which the cells transfer

electrons to the electrode is not known. There is the possibility that electron transfer might occur via the superoxide as a mediator. Generation of superoxide would be followed by the oxygen radical giving up its electron to the anode, thereby regenerating molecular oxygen. The oxygen could subsequently be reused by NADPH oxidase to produce more superoxide.

The possibility also exists that the NADPH oxidase could directly transfer the electrons to the electrodes, without employing a mediator. Further investigation into the mechanisms by which such an electron transfer takes place needs to be performed.

At the end of the experiments, a blue-green tint could be perceived at the cathode. This might be associated with the presence of unoxidized ferrocyanide compound formation. Bubbles were also observed throughout the experimental period, which indicates that some reaction is taking place, perhaps leading to gas formation or simply heat production. These bubbles might be the result of the exothermic reaction associated with the formation of water or hydrogen peroxide from hydgrogen and oxygen present in the BFC compartments.

The antioxidant NAC was used to determine whether superoxide plays a role in the current generation. Upon addition of NAC, there was a slight increase in current. At present, this observation cannot be explained. The fact that the expected decrease was not observed implies that oxygen radicals might not play a role in the electron transfer. When the non-ionic detergent, Igepal, was added, however, a noticeable decrease in the current was observed. The current was not completely extinguished. This decrease in current seems to suggest that the cells do play a role in the currents generated by the biofuel cell. The exact mechanism, however, remains a mystery. Igepal would disrupt the cellular membrane, 
rendering all membrane bound proteins dysfunctional. As a result, one would expect the currents to decrease, based on the theory that NADPH oxidase is responsible for transferring electrons to the graphite electrode.

Some important questions have been raised as a result of the previously described experiments and remain to be answered. What is contributing to the currents observed in the absence of white blood cells at the anode? To what extent are these currents affecting electron transfer from the white blood cells to the electrode? It is clear that a much more indepth investigation is required into the activity and interactivity of the various species present at the electrodes of this BFC.

The idea of a biofuel cell that could generate electricity based on various metabolic processes occurring in our own cells is very appealing. The utilization of white blood cells as a source of electrons for a biofuel cell could mark an important step in the goal of developing a perpetual power source for implantable devices. There is still a lot of work to be done as there are many unanswered questions, which have been raised as a result of the previously described experiments. 


\section{BIBLIOGRAPHY}

[1] B Alberts, A Johnson, J Lewis, M Raff, K Roberts, P Walter. "Molecular Biology of the Cell, 4th Edition," Garland Science, New York, 2002.

[2] R.M. Allen, H.P. Bennetto, "Microbial Fuel Cells," Applied Biochemistry and Biotechnology, vol. 39/40, pp. 27-40, 1993.

[3] D.R. Bond, D.E. Holmes, L.M. Tender, D.R. Lovley, "Electrode-Reducing Microorganisms that Harvest Energy from Marine Sediments," Science vol.295, pp. 483-485, January 2002.

[4] Britannica Online: http://www.search.eb.com/eb/article?idxref=51245

[5] B. Cook "Introduction to fuel cells and hydrogen technology" Engineering Science and Education Journal pp. 205-216 December 2002.

[6] D.R. Bond, D.R. Lovley, "Electricity Production by Geobacter sulfurreducens Attached to Electrodes." Applied and Environmental Microbiology vol.69, pp. 1548-1555, March 2003.

[7] M. Chiao, K.B. Lam, L. Lin, "Micromachined Microbial Fuel Cells," IEEE The Sixteenth Annual International Conference, pp. 383-386, January 2003.

[8] HR Horton, LA Moran, RS Ochs, JD Rawn, KG Scrimgeour. "Principles of Biochemistry." Prentice Hall, Inc. New Jersey (1996).

[9] National Center for Biotechnology Education (NCBE):

http://www.ncbe.reading.ac.uk/NCBE/MATERIALS/MICROBIOLOGY/fuelcell.html

[10] D. Park, S. Kim, I. Shin, Y Jeong, "Electricity Production in Biofuel Cell using modified graphite electrode with Neutral Red," Biotechnology Letters vol. 22, pp. 1301-1304, 2000.

[11] D. Park, J. Zeikus, "Improved Fuel Cell and Electrode Designs for Producing Electricity from Microbial Degradation," Biotechnology and Bioengineering, vol. 81, no. 3, pp. 348355, February 2003. 
[12] D. Park, J. Zeikus, "Electricity Generation in Microbial Fuel Cells Using Neutral Red as an Electronophore," Applied and Environmental Microbiology vol. 66, no. 4, pp. 1292-1297, April 2000.

[13] K. Rabaey, G. Lissens, S.D. Siciliano, W. Verstraete, "A microbial fuel cell capable of converting glucose to electricity at high rate and efficiency," Biotechnology Letters, vol. 25, pp. 1531-1535, July 2003.

[14] S.D. Roller, H.P. Bennetto, G.M. Delaney, J.R. Madison, J.L. Stirling, C.F. Thurston, "Electron-transfer coupling in microbial fuel cells: 1. Comparison of redox-mediator reduction rates and respiratory rates of bacteria," Journal of Chemical Technology and Biotechnology, vol. 34B, pp. 3-12, 1984.

[15] U. Schroeder, J. Niessen, F. Scholz, "A Generation of Microbial Fuel Cells with Current Outputs Boosted by More than One Order of Magnitude." Angewandte Chemie International Edition, vol. 42, pp. 2880-2883, 2003.

[16] G.M. Bokoch, U.G. Knaus, "NADPH oxidases: not just for leukocytes anymore!" Trends in Biochemical Sciences vol. 2, no. 9, pp. 502-508 September 2003.

[17] T.E. DeCoursey, V.V. Cherny, W. Zhou, L.L. Thomas, "Simultaneous activation of NADPH oxidase-related proton and electron currents in human neutrophils." Proceedings of the National Academy of Sciences vol. 97, no. 12, pp. 6885-6889, June 2000.

[18] T.E. DeCoursey, "Interactions between NADPH oxidase and voltage-gated proton channels: why electron transport depends on proton transport." Federation of European Biochemical Societies Letters vol. 555, pp. 57-61 October 2003.

[19] T.E. DeCoursey, D. Morgan, V.V. Cherny, "The voltage dependence of NADPH oxidase reveals why phagocytes need proton channels." Nature vol. 422, pp. 531-534, April 2003.

[20] J. Schrenzel, L. Serrander, B. Banfi, O. Nusse, R. Fouyouzi, D.P. Lew, N. Demaurex, K. Krause, "Electron currents generated by the human phagocyte NADPH oxidase." Nature vol. 392, pp. 734-737, April 1998. 